\title{
Municipal organic waste compost replaces mineral fertilization in the horticultural cropping systems, reducing the pollution risk
}

\author{
Massimo Zaccardelli, ${ }^{1}$ Catello Pane, ${ }^{1}$ Ida Di Mola, ${ }^{2}$ Domenico Ronga, ${ }^{3,4}$ Mauro Mori ${ }^{2}$ \\ ${ }^{1}$ Consiglio per la ricerca in agricoltura e l'analisi dell'economia agraria, Centro di ricerca Orticoltura e \\ Florovivaismo, Pontecagnano Faiano (SA); ${ }^{2}$ Dipartimento di Agraria, Università degli Studi di Napoli \\ Federico II, Portici (NA); ${ }^{3}$ Dipartimento di Scienze della Vita, Università degli Studi di Modena and Reggio \\ Emilia, Reggio Emilia; ${ }^{4}$ Dipartimento di Farmacia (DIFARMA), Università degli Studi di Salerno, Fisciano \\ (SA), Italy
}

\section{Highlights}

- Municipal solid organic waste compost (MSWC) integrated with N fertilizers can sustain vegetable production.

- MSWC (at least $30 \mathrm{t} \mathrm{ha}^{-1}$ d.w.) replaced synthetic fertilizers for tomato and eggplant productions.

- $N$ fertilizer integration to the compost residual effect is necessary to sustain endive and broccoli productions.

- MSWC (at $15 t h a^{-1}$ d.w.) needs $25 \%$ of $N$ integration to reduce the gap with plant only fertilized with $N$ fertilizer.

- MSWC preserved soil quality and avoided accumulation of undesired metals, such as Cu and Zn.

\begin{abstract}
Municipal waste compost was evaluated under open field conditions for replacing synthetic fertilizers in a vegetable three-year succession. Three compost rates, $45 \mathrm{t} \mathrm{ha}^{-1}, 30 \mathrm{tha}^{-1}$ and $15 \mathrm{t} \mathrm{ha}^{-1}$ (dry matter), and compost at $15 \mathrm{t} \mathrm{ha}^{-1}$ combined with $25 \%$, and $50 \%$ of the full synthetic nitrogen rate, were compared to full and none synthetic nitrogen fertilizations. Crop succession was: tomato followed by endive in the first year; eggplant and, then, broccoli in the second year; tomato and, then, endive/broccoli, in the third year. The application of compost at a dose of at least $30 \mathrm{tha}^{-1}$ or at $15 \mathrm{t} \mathrm{ha}^{-1}$ with the addition of $25 \%$ of the full synthetic nitrogen rate, in Spring-Summer cycle, sustained growth and yield at levels comparable with those of synthetic nitrogen fertilization. However, only a very poor residual effect of the compost soil treatment on the yield of Autumn-Winter crops, was observed.
\end{abstract}

Correspondence: Domenico Ronga, Dipartimento di Farmacia (DIFARMA), Università degli Studi di Salerno, via Giovanni Paolo II 132, 84084 Fisciano (SA), Italy.

E-mail: dronga@unisa.it

Key words: Tomato; broccoli; eggplant; endive; organic matter; soil fertilization; sustainable agriculture.

Received for publication: 17 October 2020.

Revision received: 27 February 2021.

Accepted for publication: 3 March 2021.

(C) Copyright: the Author(s), 2021

Licensee PAGEPress, Italy

Italian Journal of Agronomy 2021; 16:1756

doi:10.4081/ija.2021.1756

This article is distributed under the terms of the Creative Commons Attribution Noncommercial License (by-nc 4.0) which permits any noncommercial use, distribution, and reproduction in any medium, provided the original author(s) and source are credited.
Monitoring of nitrate content into the soil during cropping seasons, a reduction of the risk of groundwater pollution was displayed due to nitrates released by compost, respect to synthetic nitrogen fertilizer. The cumulative effects of compost application on soil properties were detected at the end of the field trials, registering changes in chemical parameters analysed, except for phosphorus and boron.

\section{Introduction}

Organic matter (OM) is a crucial factor impacting on the equilibrium of the agricultural ecosystems and soils quality. In fact, OM not only acts on soil physical structure but can also stimulate beneficial modifications in the microbial communities; soil microorganisms can also function as a source of nutrients for the plants (Albiach et al., 2000; Crecchio et al., 2004; Warman et al., 2009).

In intensive cropping systems, soils are experiencing serious losses of OM with subsequent decline in biological fertility and soil quality due to their excessive exploitation, abandonment of rotations, high intensity and frequency of soil tillage, and wide use of synthetic fertilizers (Celano et al., 2012). In addition, in Mediterranean environments the losses of OM are also accelerated by the specific climatic conditions like the succession of drywarm to humid-temperate seasons which boost the OM degradation (Cala et al., 2005).

In degraded soils, the cycle of OM is not balanced, with a subsequent reduction of the accumulation of organic residues and their humification. In these contests, it become very real the risks of soil characterized by low fertility, with the progressive decrease of crop yield sustainability (Pane et al., 2010). In these degraded soils, in order to reach global fertility recovery, it is indispensable to maintain a fragile equilibrium between accumulation and consumption of OM, through addition of exogenous organic amendments such as waste compost (Pane et al., 2012a). Municipal solid organic waste (MSW) composts (MSWC) are a source of stable and mature $\mathrm{OM}$ obtained as final product of an activate aerobic 
solid-state fermentation of urban biosolids. Therefore, waste compost amendment can be considered as an agronomically interesting practice, very important for the development of sustainable lowinput agricultural systems. In addition waste compost amendment may have a role in the safe waste management strategies (Zucconi and De Bertoldi, 1986; Hargreaves et al., 2008a; Ronga et al., 2016; Ronga et al., 2019a, 2019b; Setti et al., 2019; Bortolini et al., 2020; Ronga et al., 2020a). In fact, the agricultural utilization of MSW not only decreases the high pressure on land for landfilling, but it also improves soil fertility and acts as a soil conditioner (Singh and Agrawal 2008, 2010). Moreover, MSWC can have other roles: i) restoration of ecologic and economic functions of degraded land (Shiralipour et al., 1992); ii) restoration of wildfire burnt soil (Guerrero et al., 2001; Kowaljowa and Mazzarino, 2007; Kowaljow et al., 2010); iii) remediation of pollutants (Semple et al., 2001) and hydrocarbons (Sarkar et al., 2005); iv) prevention of desertification (Bastida et al., 2007a); v) restoration of forest soil (Bastida et al., 2007b); vi) remediation of saline soil (Tejada et al., 2006; Lakhdar et al., 2009).

The specific use of MSWC in agriculture as amendment has several beneficial effects on soil and yield. Waste compost enhances chemical, physical and biological soil properties (Crecchio et al., 2004); it has a high content of nitrogen, humic substances and organic matter (Garcia-Gil et al., 2004), playing a key role in maintaining soil quality (Pedra et al., 2007) and improving the physico-chemical and biological properties of soil (Araujo et al., 2010). Several researchers reported that repeated application of MSWC in agricultural land helps in increasing the organic matter content and $\mathrm{C} / \mathrm{N}$ ratio of soil in comparison to unamended soil (Crecchio et al., 2004; Garcia-Gil et al., 2004; Hargreaves et al., 2008a, 2008b, 2008c).

Obviously, the MSWC is also a source of nutrients, but it has many advantages over inorganic fertilizers, whose increasing and uncorrected use has negatively affected the physical, chemical and biological properties of soil in the last decades (Mathivanan et al., 2012). In fact, a long-term use of inorganic fertilizers may change soil $\mathrm{pH}$ and disturb the soil microbiota (Srivastava et al., 2016) and can cause environmental damages, such as nitrates leaching towards the groundwater and increasing greenhouse gases emissions in relation to the increased nitrogen fertilization rate (Ronga et al., 2019c). Instead, the MSWC application boosts plants yield and improves soil nutrient profile, microbial activity, soil structural stability and buffering capacity (Hargreaves et al., 2008a, 2008b, 2008c; Carbonell et al., 2011; Bouzaiane et al., 2014; Weber et al., 2014). Furthermore, in agricultural soils, compost addition increases porosity, structural stability, moisture, root aeration and protects soil from erosion (Pinamonti et al., 1997; Aggelides and Londra, 2000; Garcia-Gil et al., 2000; Ramos and MartınezCasasnovas, 2006; Weber et al., 2007).

Finally, the waste compost elicits plant biostimulation (Zaccardelli et al., 2012), disease suppression (Conklin et al., 2002; Pane et al., 2011; Paradelo et al., 2012) and useful microflora development (Green et al., 2004; Pane et al., 2012b). Therefore, its application could be proposed to replace inputs such as synthetic fertilizers (Zaccardelli et al., 2006) and/or fungicides (Pane et al., 2012c).

The utilization of the municipal solid organic waste, as soil amendment, has also a very important environmental value, by avoiding disposal in landfill or incineration.

However, the MSWC has also some limits due to the content of heavy metals (i.e., $\mathrm{Cd}, \mathrm{Cu}, \mathrm{Zn}, \mathrm{Pb}$, etc.), which can accumulate in soil and, then, absorbed by the crops with significant risks for human health (Srivastava et al., 2016). Moreover, MSWC some- times has high salt concentration that can have negative effect on soil structural stability and plants growth (Hargreaves et al., 2008a). Finally, another potential risk of using MSWC may be the presence of pathogens that are not eliminated in the composting process like thermophilic pathogens.

The advantages of MSWC are unquestionable, but further studies are necessary to clarify the effects of compost application to open field vegetable cropping systems, especially considering crop rotations.

The aim of this study was to assess the effect of a MSWC on vegetable crops with spring-summer crop cycle (tomato and eggplant) and autumn-winter crop cycle (endive and broccoli) over three-year trials in a Mediterranean environment. The experiments were carried out comparing different compost rates to traditional farm fertilization. In this work, it was evaluated the agronomic response of the crops and the modifications on soil chemical composition affected by the investigated treatments.

\section{Materials and methods}

\section{Experimental fields and treatments}

Field was located at the experimental farm of Research Centre for Vegetable Crops (Battipaglia, Sele Valley, Salerno District, Campania Region), on a clay-loam (43.9\% sand, $27.8 \%$ silt and $28.3 \%$ clay) sub-alkaline soil ( $\mathrm{pH} 7.6)$ with normal salinity $(0.114$ $\mathrm{dS} \mathrm{m}^{-1}$ ), mean cation exchange capacity (CEC; 16.95 meq $100 \mathrm{~g}^{-1}$ ), very low total limestone $(3.5 \%)$, low content of organic matter $(1.3 \%)$ and total nitrogen $(0.08 \%)$ and high content of available phosphorous (P) (47 ppm, Olsen method) and exchangeable potassium $\left(\mathrm{K}_{2} \mathrm{O}\right)(426 \mathrm{ppm})$. Trials were carried-out from spring 2003 to winter 2005/2006. Treatments followed an experimental design organized in complete randomized block with three replications and were: plots treated with 15 (C15, corresponding to $261,307.5$ and $172.5 \mathrm{~kg}$ of $\mathrm{N} \mathrm{ha}^{-1}$, in the first second and third year, respectively), 30 (C30, corresponding to 522,615 and $345 \mathrm{~kg}$ of $\mathrm{N} \mathrm{ha}^{-1}$, in the first second and third year, respectively) and 45 (C45, corresponding to $783,922.5$ and $517.5 \mathrm{~kg}$ of $\mathrm{N} \mathrm{ha}^{-1}$, in the first second and third year, respectively) $\mathrm{t} \mathrm{ha}^{-1}$ from Municipal solid organic waste compost (MSWC) on dry matter (d.m.) basis; plots treated with NPK synthetic fertilizers (MIN); plots treated with $15 \mathrm{t} \mathrm{ha}^{-1}$ d.m. of compost plus $25 \%(\mathrm{C} 15+\mathrm{N} 25 \%)$, or $50 \%(\mathrm{C} 15+\mathrm{N} 50 \%)$ of synthetic nitrogen used in MIN; plots not amended and not fertilized (CNT). Area of each plot was $68 \mathrm{~m}^{2}$. Compost rates were chosen to estimate the amount necessary to replace synthetic fertilizers in a vegetable cropping system providing invariable levels of yield. Compost rates were also based on previous works focused on topics regarding: i) organic carbon sequestration into soil (Pagano et al., 2008); and ii) evolution of soil bioindicators (Iovieno et al., 2009).

\section{Compost characteristics and fertilization}

The compost used in this study was a commercial 1-year old biowaste compost, originated from a mixture of municipal solid wastes and pruning residues $(50 / 50, \mathrm{w} / \mathrm{w})$, purchased from Gesenu (Perugia, Italy). Composting was made with a static forced aeration system for one month and, after that, with natural aeration for about two months. Compost was incorporated in the soil on April $9^{\text {th }}, 2003$, on May $10^{\text {th }}, 2004$ and on April $1^{\text {st }}, 2005$. Composition of the used composts are reported in Table 1. In all composts, contents of heavy metals, inert and plastic materials were within legal 
thresholds; salmonellas, cestodes, nematodes and trematodes were absent as reported on the label. Compost was incorporated at 15$20 \mathrm{~cm}$ depth, generally 2 weeks before transplanting of the spring crop. For MIN plots, $\mathrm{P}$ and $\mathrm{K}$ mineral fertilizers were distributed as mineral perphosphate and potassium sulphate before transplanting of the crops, whereas $\mathrm{N}$ fertilizer was distributed for $1 / 3$ before transplanting (ammonium sulphate) and for $2 / 3$ (ammonium nitrate) in two top-dressing distributions, for both spring and winter crops.

\section{Crops and cultural techniques}

The experimental field was previously cropped with wheat. Crops under study were: tomato (Solanum lycopersicum L.), followed by endivia (Cichorium indivia L. var. crispum Hegi), cultivated during 2003; eggplant (Solanum melongena L.), followed by broccoli (Brassica rapa L. subsp. sylvestris L. Janch. var. esculenta Hort.), cultivated during 2004; tomato, followed by endive and broccoli both cultivated simultaneously on two sub-plots, during 2005/06.

Tomato, cultivar Galeon (peeled tomato with determinate growth habit) was transplanted on April 23 ${ }^{\text {rd }}, 2003$ and on April $28^{\text {th }}, 2005$, with a density of 29,000 plants ha $^{-1}$. MIN treatment was based on the supply of $150 \mathrm{~kg} \mathrm{ha}^{-1}$ of N, $200 \mathrm{~kg} \mathrm{ha}^{-1}$ of $\mathrm{P}_{2} \mathrm{O}_{5}$ and $120 \mathrm{~kg} \mathrm{ha}^{-1}$ of $\mathrm{K}_{2} \mathrm{O}$, following the common practices of the investigated area. Fruits were harvested on August $6^{\text {th }}, 2003$ and on August $5^{\text {th }}, 2005$.

For eggplant, cultivar Arrow was transplanted on May $20^{\text {th }}$, 2004 , with a density of 16,650 plants $\mathrm{ha}^{-1}$. MIN plots were fertilized with $100 \mathrm{~kg} \mathrm{ha}^{-1}$ of $\mathrm{N}, 80 \mathrm{~kg} \mathrm{ha}^{-1}$ of $\mathrm{P}_{2} \mathrm{O}_{5}$ and $120 \mathrm{~kg} \mathrm{ha}^{-1}$ of $\mathrm{K}_{2} \mathrm{O}$. Fruits were harvested from July $15^{\text {th }}$ to August $26^{\text {th }}, 2004$, for a total of seven harvest times.

For endive, cultivar Dolly was transplanted on September $30^{\text {th }}$, 2003 and on October $13^{\text {th }}, 2005$, with a density of 94,000 plants $\mathrm{ha}^{-1}$. MIN plots were fertilized with $150 \mathrm{~kg} \mathrm{ha}^{-1}$ of $\mathrm{N}, 100 \mathrm{~kg} \mathrm{ha}^{-1}$ of $\mathrm{P}_{2} \mathrm{O}_{5}$ and $200 \mathrm{~kg} \mathrm{ha}{ }^{-1}$ of $\mathrm{K}_{2} \mathrm{O}$. Plants were harvested on December 29 $9^{\text {th }}, 2003$ and on February $28^{\text {th }}, 2005$.

For broccoli, local variety Novantina was transplanted on October $8^{\text {th }}, 2004$ and on October $12^{\text {th }}, 2005$, with a density of 55,550 plants ha ${ }^{-1}$. MIN plots were fertilized with $200 \mathrm{~kg} \mathrm{ha}^{-1}$ of $\mathrm{N}, 60 \mathrm{~kg} \mathrm{ha}^{-1}$ of $\mathrm{P}_{2} \mathrm{O}_{5}$ and $200 \mathrm{~kg} \mathrm{ha}^{-1}$ of $\mathrm{K}_{2} \mathrm{O}$. Plants were harvested on January $7^{\text {th }}, 2005$ and on January $24^{\text {th }}, 2006$, respectively.

For all crops, cultural technique and crop protection were performed according to integrated production protocol of Campania Region.

\section{Bio-productive and growth measurements}

Onto an assay area of $8.16 \mathrm{~m}^{2}$, corresponding to 20 plants per plot, total and marketable yield of tomato fruits were evaluated. On a sample of 100 fruits per plot, fresh weight, length and width of the fruits, incidence of biotic and abiotic damages (aside from virus symptoms and sunburn) were evaluated.

On eggplant, for each harvest, on an assay area of about $6 \mathrm{~m}^{2}$, corresponding to 10 plants per plot, precocious and total marketable yield, number of fruits and, on a representative sample, diameter, length and weight of the fruits, were evaluated.

On endive, on an assay area of $2.13 \mathrm{~m}^{2}$, corresponding to 20 plants per plot, total yield, expressed as fresh weight, colour of the heads visually determined as light, mean and dark were assessed. In addition, on a representative number of heads (corresponding to five plants), diameter, fresh mean weight and succulence $\left(\mathrm{mg} \mathrm{H}_{2} \mathrm{O}\right.$ $\mathrm{cm}^{-2}$ of leaf surface), were also evaluated.

Onto an assay area of $3.6 \mathrm{~m}^{2}$, corresponding to 20 plants per plot, total and marketable fresh and dry weight of aerial biomass of broccoli, were evaluated.

Moreover, for the four more representative treatments $(\mathrm{C} 15$, C45, MIN and CNT) growth analysis was recorded for all tested crops, in three times of cycle (the sampling dates of each crop are reported in the relative tables). Two plants per replicate were sampled, then divided in the different organs and weighed separately. Finally, the all-plant organs were oven-dried at $60^{\circ} \mathrm{C}$ in order to determining the dry matter.

\section{Chemical analyses of crop products}

A sample of tomato ripe fruits per plot was analysed to determine dry matter, optical residues $\left({ }^{\circ} \mathrm{Bx}\right), \mathrm{pH}$, glucose and fructose, to verify attitude to industrial transformation. Dry matter content, ${ }^{\circ} \mathrm{Bx}$, acidity, $\mathrm{pH}$ and colour were determined according to the Italian official analysis methods (G.U. no. 168/1989); sugars were determined by high performance liquid chromatography (HPLC) (Ronga et al., 2020b).

Sample of endive and broccoli were analysed for nitrate contents in the marketable products (heads of endive, leaves and inflorescence of broccoli). Nitrate were determined by flow injection colorimetric method (Griess-Ilosvay reaction) according to the Italian directive (G.U. no. 177/1999).

\section{Chemical analyses of soil samples}

Before compost amendment in 2003 and at the end of the triennial crop succession in 2006, soil samples were collected at 0-20 and 20-40 cm deep. Each soil sample was obtained mixing five soil sub-samples collected from each experimental plot.

Chemical analyses performed on all soil samples were: soil reaction $(\mathrm{pH})$, electrical conductivity (EC), OM, total $\mathrm{N}$, absorbable $\mathrm{P}, \mathrm{Fe}, \mathrm{Mn}, \mathrm{Cu}$ and $\mathrm{Zn}$, exchangeable $\mathrm{K}_{2} \mathrm{O}, \mathrm{Na}, \mathrm{Ca}$ and $\mathrm{Mg}$, soluble $\mathrm{B}$ and cation exchange capacity (CEC). All analyses were performed according to the Official Methods of Soil Analysis, Part 3-Chemical Methods, of Soil Science Society of America (SSSA, 1996).

In addition, on the four chosen treatments $(\mathrm{C} 15, \mathrm{C} 45, \mathrm{MIN}$ and $\mathrm{CNT}$ ) soil analysis were made in order to measure the nitrate content by a spectrophotometer Hach DR 2000 (Hach Co., Loveland, $\mathrm{CO}$ ), and total nitrogen by Kjeldhal method (Kjeldahl, 1883), on samples collected at two depths $(0-20$ and $20-40 \mathrm{~cm})$ during the whole cycles. The nitrate determination $\left(\mathrm{N}^{\left.-\mathrm{NO}_{3}\right)}\right.$ was made on

Table 1. Composition of the composts used in this study. Values are referred to dry matter.

\begin{tabular}{|c|c|c|c|c|c|}
\hline \multirow[t]{2}{*}{ Manufacturing year } & \multicolumn{5}{|c|}{ Parameters } \\
\hline & $\begin{array}{l}\text { Total organic carbon } \\
\left({\left.\mathrm{g} \mathrm{g} 100 \mathrm{~g}^{-1}\right)}\right.\end{array}$ & $\begin{array}{l}\text { Total nitrogen } \\
\left(\mathrm{g} 100 \mathrm{~g}^{-1}\right)\end{array}$ & $\begin{array}{l}\text { Total organic nitrogen } \\
\qquad\left(\mathrm{g} 100 \mathrm{~g}^{-1}\right)\end{array}$ & C-to-N ratio & $\mathrm{pH}$ \\
\hline $1^{\text {st-year }}$ & 24.0 & 1.74 & 1.47 & 16.0 & 7.50 \\
\hline $2^{\text {nd }}$-year & 33.7 & 2.05 & 1.98 & 16.4 & 7.51 \\
\hline $3^{\text {rd }}$-year & 29.4 & 1.15 & 1.04 & 28.0 & 8.49 \\
\hline
\end{tabular}


water extract of oven-dried soil samples, according to the cadmium reduction method proposed by Sah (1994). The absorbance of the solution was determined at $500 \mathrm{~nm}$ wavelength, and the final result was expressed in ppm. The Kjeldhal method is a wet oxidation method, basing on use of concentrated sulfuric acid. During the Kjeldahl digestion, the use of a catalyst allows to accelerate oxidation and complete the digestion for determining the nitrogen content. The quantification of distilled ammonia is generally achieved by titration; the ammonia is absorbed in an excess of boric acid, followed by titration with standard acid in the presence of a suitable indicator.

\section{Statistical analyses}

All data were statistically analysed by analysis of variance and means were separated by Duncan's range test, applied at a probability (P) level $\leq 0.05$. Statistical analyses were performed using the software MSTAT-C (A Microcomputer Program for the Design, Management and Analysis of Agronomic Research Experiments, Michigan State University, USA, 1988).

\section{Results}

\section{Spring-summer cycle}

The interaction 'year $\times$ fertilization' and the main effect of year were never significant for total and marketable yield of tomato and precocious and marketable yield of eggplants, thus in Figure 1A and $\mathrm{B}$ only the statistically significant effect of the fertilization treatments is reported.

Results showed that MSWC treatments, apart for C15, affected positively the productivity of two Spring-Summer crops, tomato and eggplant, at the same level of MIN treatment. In fact, C15 amended plots and not-treated control plots showed intermediate and lower yields, respectively. In detail, total and marketable yield of tomato in the fertilized plots, excluding $\mathrm{C} 15$, were on average, 40.57 and $39.40 \mathrm{t} \mathrm{ha}^{-1}$, respectively, and were higher than that of

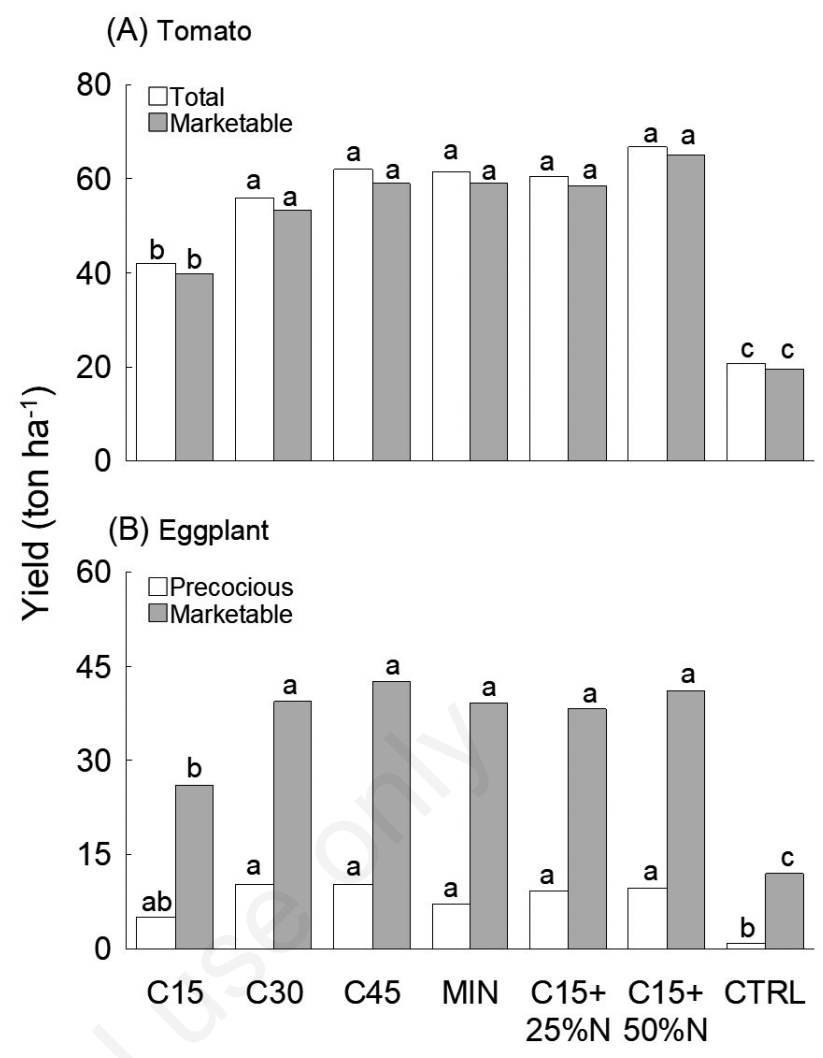

Figure 1. Total and marketable yield of tomato (A) and precocious and total yield of eggplant (B). Columns in the same graph with the same letter are not significantly different for $\mathbf{P} \leq \mathbf{0 . 0 5}$ according to Duncan's range test. Whiskers indicate the standard error interval (sample size: 3 replicates (and 20 pseudoreplications for each replicate) for tomato and 3 replicates for eggplant (and 10 pseudoreplications for each replicate).

Table 2. Bio-morphological and qualitative characters measured on marketable tomato fruits.

\begin{tabular}{|c|c|c|c|c|c|c|c|c|c|c|c|c|c|}
\hline Treatments & $\begin{array}{c}\text { Average } \\
\text { weight } \\
\text { (g) }\end{array}$ & $\begin{array}{l}\text { Length } \\
\text { (cm) }\end{array}$ & $\begin{array}{l}\text { Width } \\
\text { (cm) }\end{array}$ & $\begin{array}{c}\text { Sunburn } \\
\text { fruit } \\
(\%)\end{array}$ & $\begin{array}{c}\text { Viral } \\
\text { damages } \\
(\%)\end{array}$ & $\begin{array}{c}\text { Biotic } \\
\text { damages } \\
(\%)\end{array}$ & $\begin{array}{l}\text { Amato frui } \\
\text { Abiotic } \\
\text { damages } \\
(\%)\end{array}$ & $\begin{array}{l}\text { Dry } \\
\text { residue } \\
(\%)\end{array}$ & $\begin{array}{c}\text { Optical } \\
\text { residue } \\
\left({ }^{\circ} \mathrm{Bx}\right)\end{array}$ & $\begin{array}{l}\text { Acidity } \\
(\%)\end{array}$ & $\begin{array}{l}\text { Glucose } \\
\qquad(\mathrm{g} \%)\end{array}$ & $\begin{array}{l}\text { Fructose } \\
(\mathrm{g} \%)\end{array}$ & $\begin{array}{l}\text { pH } \\
(-)\end{array}$ \\
\hline $\mathrm{C} 15$ & 62.2 & $7.9^{\mathrm{a}}$ & $4.1^{\mathrm{a}}$ & $5.5^{\mathrm{b}}$ & $15.2^{\mathrm{b}}$ & 1.5 & $2.7^{\mathrm{ab}}$ & 5.68 & 4.98 & 0.26 & 1.60 & 1.76 & 4.48 \\
\hline C30 & 57.4 & $7.7^{\mathrm{ab}}$ & $4.0^{\mathrm{ab}}$ & $4.0^{\mathrm{b}}$ & $17.2^{\mathrm{ab}}$ & 1.5 & $2.7^{a b}$ & 5.77 & 5.04 & 0.28 & 1.59 & 1.78 & 4.50 \\
\hline C45 & 56.2 & $7.6^{b}$ & $3.9^{a b}$ & $6.0^{\mathrm{b}}$ & $22.2^{a b}$ & 2.5 & $1.5^{b}$ & 5.71 & 5.10 & 0.27 & 1.60 & 1.82 & 4.49 \\
\hline MIN & 54.3 & $7.7^{\mathrm{ab}}$ & $3.9^{\mathrm{ab}}$ & $4.0^{\mathrm{b}}$ & $25.2^{\mathrm{a}}$ & 3.3 & $2.5^{\mathrm{ab}}$ & 5.77 & 5.21 & 0.25 & 1.54 & 1.72 & 4.60 \\
\hline $\mathrm{C} 15+25 \% \mathrm{~N}$ & 59.4 & $7.7^{a b}$ & $4.0^{a b}$ & $4.5^{b}$ & $19.0^{\mathrm{ab}}$ & 1.8 & $2.3^{a b}$ & 5.75 & 5.10 & 0.25 & 1.60 & 1.80 & 4.50 \\
\hline $\mathrm{C} 15+50 \% \mathrm{~N}$ & 57.0 & $7.7^{a b}$ & $4.0^{\mathrm{ab}}$ & $5.2^{\mathrm{b}}$ & $21.2^{\mathrm{ab}}$ & 2.8 & $1.7^{\mathrm{b}}$ & 5.64 & 5.04 & 0.24 & 1.56 & 1.72 & 4.55 \\
\hline CNT & 56.1 & $7.9^{a}$ & $3.8^{b}$ & $10.2^{a}$ & $19.3^{\mathrm{ab}}$ & 3.7 & $4.0^{\mathrm{a}}$ & 5.82 & 5.09 & 0.26 & 1.64 & 1.83 & 4.46 \\
\hline I Year & 59.7 & 8.1 & 4.1 & 5.1 & 30.6 & 3.2 & 4.5 & 5.59 & 4.85 & 0.27 & 1.57 & 1.75 & 4.45 \\
\hline II Year & 55.3 & 7.4 & 3.9 & 6,1 & 9.7 & 1.7 & 0.40 & 5.89 & 5.32 & 0.25 & 1.61 & 1.81 & 4.57 \\
\hline \multicolumn{14}{|l|}{ Effect $^{\circ}$} \\
\hline Treat. & ns & $*$ & * & $*$ & $*$ & ns & $*$ & ns & ns & ns & ns & ns & ns \\
\hline Year & $*$ & $*$ & $*$ & ns & $*$ & * & $*$ & $*$ & * & ns & ns & ns & ns \\
\hline Treat.xYear & ns & ns & ns & ns & ns & ns & ns & ns & ns & ns & ns & ns & ns \\
\hline
\end{tabular}

a,bNumbers in the same column followed by the same letter are not significantly different for P-value $\leq 0.05$ according to Duncan's range test; ${ }^{\circ}$ Main factors of the two-way ANOVA. Asterisks indicates significance at P-value $\leq 0.05$; ns, not significant. 
the control plots, with a $195 \%$ and $202 \%$ net yield improvement between, respectively (Figure 1A). Production in C15 was, on the average, higher than that of the control plots, with a $100 \%$ increment (Figure 1A). The marketable yield of eggplant in the fertilized plots, excluding $\mathrm{C} 15$, were, on the average, higher than that of the control plots, with a $216 \%$ yield improvement (Figure 1B). On average, also eggplant production in $\mathrm{C} 15$ was, higher than that of the control plots, with a $116 \%$ increment (Figure 1B). Only few tomato fruit characteristics (viral and abiotic damages, length and width) were significantly $(\mathrm{P} \leq 0.05)$ affected by fertilization treatments (Table 2) but, unfortunately, the observed effects were slight and not always clear. In contrast, biometric measurements on eggplant berries revealed a significant increment of size due to fertilization treatments, compared to the control (Table 3). In fact, all plots fertilized with compost and/or with nitrogen and mineral fertilizers, provided fruits with the same mean weight, length and diameter, with value statistically higher than CNT (Table 3). No relevant differences were registered among treatments for colour (black) and form (long) of the fruits (data not shown).

The crop growth data of the four chosen treatments (C15, C45, $\mathrm{MIN}$ and control) are reported, as effect of fertilization on dry matter distribution to the different organs of plant, in Tables 4 and 5, for tomato and eggplant, respectively. Over the three samplings the percentage incidence of aboveground biomass without fruits (stems + leaves + flowers) decreased, ranging from $82.4 \%$ (mean value of the four treatments) of the first sampling to $32.4 \%$ of the last sampling. At the first sampling, the MIN tomato plants showed a higher incidence of fruits on total dry matter than all other treatments. At the same sampling, the percentage incidence of $\mathrm{C} 15$ fruits was no different from that of control plants. Instead, at the second sampling the values of the percentage fruits on total dry matter of the three fertilization treatments were similar among them and statistically different from control. Finally, about the root incidence on total dry matter, at the third sampling the control plants showed a value statistically higher than all other treatments (Table 4). For the eggplants, the trend of aboveground biomass was similar to that observed in tomato, but the range of values was less large (from $89.8 \%$ of first sampling to $65.6 \%$ of third sampling). Here too, the control plants gave fruits later than all other treatments, only at the third sampling; moreover, the biomass allocated to roots of control plants was statistically higher than the other plants, in the third samplings (Table 5), when it was statistically different from all other treatments. Finally, at the third sampling, the $\mathrm{C} 45$ plants showed a higher value of biomass allocated to fruits statistically different from the other treatments.

\section{Autumn-winter cycle}

As shown for tomato and eggplant, also for broccoli and endive the interaction between year and fertilization treatments was not significant for the yield; only the main effect of fertilization was significant, as showed in Figure 2A and B, for endive and broccoli, respectively. Yields of broccoli and endive as fresh and dry biomass values were the highest in MIN plots and the lowest in control plots (Figure 2A and B). The dose of compost and the synthetic $\mathrm{N}$-integrated rate also significantly affected the yield.

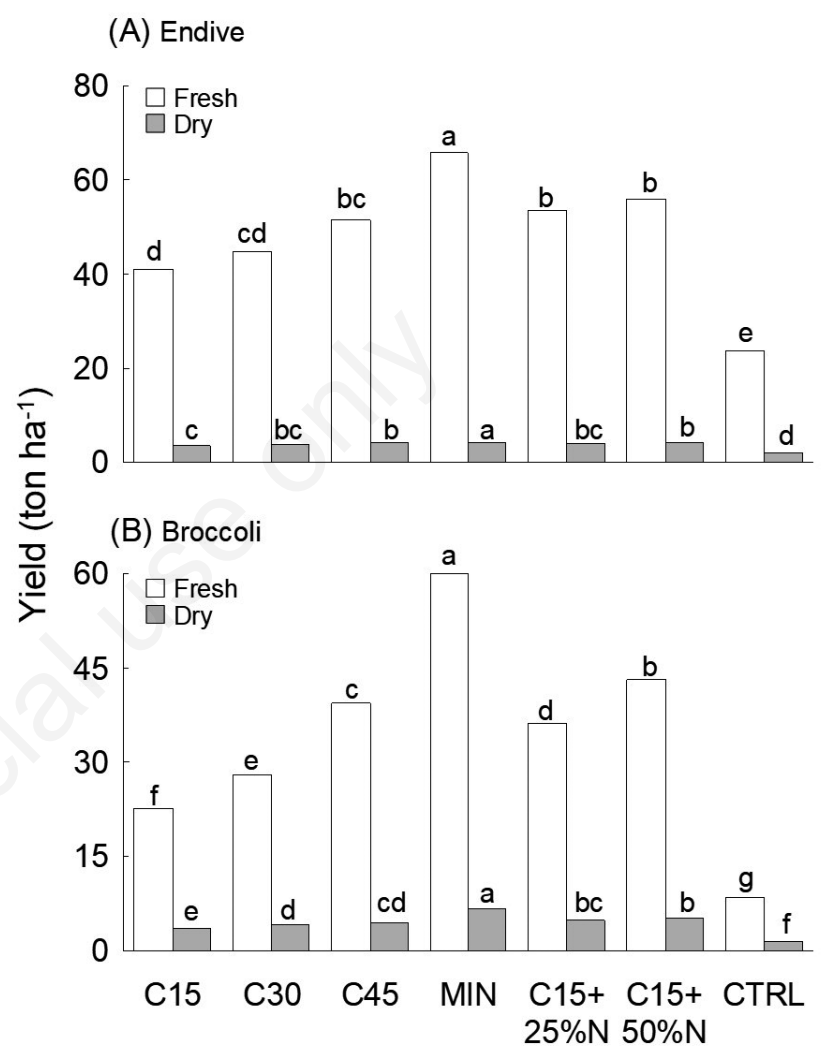

Figure 2. Fresh and dry yield of endive (A) and broccoli (B). Columns in the same graph with the same letter are not significantly different for $\mathrm{P} \leq \mathbf{0 . 0 5}$ according to Duncan's range test. Whiskers indicate the standard error interval (sample size: 3 replicates, and 20 pseudoreplications for each replicate, for endive and broccoli).

Table 3. Effects of compost and mineral fertilizers applications on number and dimension of eggplant fruits.

\begin{tabular}{|c|c|c|c|c|}
\hline \multirow[b]{2}{*}{ Treatments } & \multicolumn{4}{|c|}{ Eggplant berries } \\
\hline & Number $\left(x 1000 \mathrm{ha}^{-1}\right)$ & Mean weight (g) & Length (cm) & Diameter (mm) \\
\hline $\mathrm{C} 15$ & $202.8^{b}$ & $129^{a}$ & $17.2^{\mathrm{ab}}$ & $52^{\mathrm{a}}$ \\
\hline C30 & $298.3^{\mathrm{a}}$ & $132^{\mathrm{a}}$ & $17.3^{\mathrm{ab}}$ & $54^{\mathrm{a}}$ \\
\hline C45 & $323.9^{a}$ & $133^{\mathrm{a}}$ & $17.4^{\mathrm{ab}}$ & $54^{\mathrm{a}}$ \\
\hline MIN & $304.4^{\mathrm{a}}$ & $128^{a}$ & $17.4^{\mathrm{a}}$ & $53^{\mathrm{a}}$ \\
\hline $\mathrm{C} 15+25 \% \mathrm{~N}$ & $282.2^{\mathrm{a}}$ & $135^{\mathrm{a}}$ & $16.8^{\mathrm{ab}}$ & $54^{\mathrm{a}}$ \\
\hline $\mathrm{C} 15+50 \% \mathrm{~N}$ & $302.8^{a b}$ & $136^{\mathrm{a}}$ & $17.1^{\mathrm{ab}}$ & $54^{\mathrm{a}}$ \\
\hline $\mathrm{CNT}$ & $108.9^{c}$ & $110^{b}$ & $14.3^{\mathrm{c}}$ & $48^{b}$ \\
\hline \multicolumn{5}{|l|}{ Effect } \\
\hline Treat. & $*$ & $*$ & $*$ & $*$ \\
\hline
\end{tabular}

${ }^{a-c}$ Numbers in the same column followed by the same letter are not significantly different for P-value $\leq 0.05$ according to Duncan's range test. Asterisks indicates significance at P-value $\leq 0.05$. 
Compost treatments, also without synthetic $\mathrm{N}$ integration, elicited in the endive an increment of fresh yield compared to control, yield that ranged between $12.93 \mathrm{tha}^{-1}$ for $\mathrm{C} 15$ and 31.52 for $\mathrm{C} 15+50 \mathrm{~N}$ and of dry yield between $1.10 \mathrm{t} \mathrm{ha}^{-1}$ for $\mathrm{C} 15$ and $2.14 \mathrm{t} \mathrm{ha}^{-1}$ for $\mathrm{C} 45$, equivalent, on average, to an increased fresh productivity of about $72-176 \%$ (Figure 2A). Integration of compost amendment with synthetic $\mathrm{N}$ did not increase significantly the yield, beyond the values showed by treatment $\mathrm{C} 45$. Biometrical parameters of endive followed the same trend of productivity, as well as leaves nitrate content (Table 6).

Table 4. Effect of fertilization treatments on dry matter distribution to the different organs (average value of the two years) of tomato plant in three sampling dates, expressed as days after transplant. The values are the mean of 6 values \pm standard error.

\begin{tabular}{|c|c|c|c|c|c|c|c|c|c|c|c|}
\hline $\begin{array}{l}\text { DATI } \\
30\end{array}$ & $\begin{array}{l}\text { Treatments } \\
\mathrm{C} 15\end{array}$ & \multicolumn{2}{|c|}{$\begin{array}{l}\text { Roots d.m. } \\
\%\end{array}$} & \multicolumn{2}{|c|}{$\begin{array}{c}\text { Stems d.m. } \\
\%\end{array}$} & \multicolumn{2}{|c|}{$\begin{array}{c}\text { Leaves d.m. } \\
\%\end{array}$} & \multicolumn{2}{|c|}{$\begin{array}{c}\text { Flowers d.m. } \\
\%\end{array}$} & \multicolumn{2}{|c|}{$\begin{array}{c}\text { Fruits d.m. } \\
\qquad \%\end{array}$} \\
\hline 30 & $\begin{array}{l}\text { C15 } \\
\text { C45 } \\
\text { MIN } \\
\text { CNT }\end{array}$ & $\begin{array}{l}7.6 \\
8.8 \\
8.2 \\
7.6\end{array}$ & $\begin{array}{l} \pm 0.3 \\
\pm 0.6 \\
\pm 0.3 \\
\pm 0.1\end{array}$ & $\begin{array}{l}17.8 \\
19.6 \\
17.7 \\
15.9\end{array}$ & $\begin{array}{l} \pm 1.5 \\
\pm 0.2 \\
\pm 0.8 \\
\pm 1.3\end{array}$ & $\begin{array}{l}61.0 \\
60.3 \\
56.6 \\
62.3\end{array}$ & $\begin{array}{l} \pm 1.0 \\
\pm 1.7 \\
\pm 0.4 \\
\pm 3.1\end{array}$ & $\begin{array}{l}4.4 \\
4.1 \\
5.0 \\
4.6\end{array}$ & $\begin{array}{l} \pm 0.3 \\
\pm 0.4 \\
\pm 0.2 \\
\pm 0.4\end{array}$ & $\begin{array}{c}9.1 \\
7.2 \\
12.6 \\
9.6\end{array}$ & $\begin{array}{l} \pm 1.5 \\
\pm 1.0 \\
\pm 0.9 \\
\pm 1.2\end{array}$ \\
\hline 60 & $\begin{array}{l}\text { C15 } \\
\text { C45 } \\
\text { MIN } \\
\text { CNT }\end{array}$ & $\begin{array}{l}4.5 \\
3.9 \\
3.5 \\
4.9\end{array}$ & $\begin{array}{l} \pm 0.2 \\
\pm 0.2 \\
\pm 0.3 \\
\pm 0.2\end{array}$ & $\begin{array}{l}12.9 \\
12.4 \\
10.5 \\
13.8\end{array}$ & $\begin{array}{l} \pm 1.1 \\
\pm 1.0 \\
\pm 0.4 \\
\pm 1.3\end{array}$ & $\begin{array}{l}26.9 \\
27.2 \\
27.3 \\
32.0\end{array}$ & $\begin{array}{l} \pm 2.0 \\
\pm 1.7 \\
\pm 0.3 \\
\pm 0.4\end{array}$ & $\begin{array}{l}4.3 \\
4.2 \\
4.1 \\
4.6\end{array}$ & $\begin{array}{l} \pm 0.1 \\
\pm 0.1 \\
\pm 0.1 \\
\pm 0.2\end{array}$ & $\begin{array}{l}51.5 \\
52.4 \\
54.6 \\
44.7\end{array}$ & $\begin{array}{l} \pm 3.3 \\
\pm 2.8 \\
\pm 0.9 \\
\pm 1.5\end{array}$ \\
\hline 90 & $\begin{array}{l}\text { C15 } \\
\text { C45 } \\
\text { MIN } \\
\text { CNT }\end{array}$ & $\begin{array}{l}2.8 \\
2.6 \\
2.4 \\
3.6 \\
\end{array}$ & $\begin{array}{l} \pm 0.4 \\
\pm 0.1 \\
\pm 0.1 \\
\pm 0.1\end{array}$ & $\begin{array}{c}10.6 \\
10.4 \\
9.3 \\
11.7 \\
\end{array}$ & $\begin{array}{l} \pm 1.6 \\
\pm 0.9 \\
\pm 0.5 \\
\pm 0.6\end{array}$ & $\begin{array}{l}18.7 \\
17.7 \\
17.5 \\
20.0\end{array}$ & $\begin{array}{l} \pm 0.2 \\
\pm 1.7 \\
\pm 0.1 \\
\pm 1.1\end{array}$ & $\begin{array}{l}3.5 \\
3.4 \\
3.6 \\
3.3 \\
\end{array}$ & $\begin{array}{l} \pm 0.4 \\
\pm 0.3 \\
\pm 0.1 \\
\pm 0.1 \\
\end{array}$ & $\begin{array}{l}64.4 \\
66.0 \\
67.1 \\
61.3 \\
\end{array}$ & $\begin{array}{l} \pm 2.6 \\
\pm 2.8 \\
\pm 0.6 \\
\pm 1.5\end{array}$ \\
\hline
\end{tabular}

DAT, days after transplant; d.m., dry matter.

Table 5. Effect of fertilization treatments on dry matter distribution to the different organs of eggplant plant in three sampling dates, expressed as days after transplant. The values are the mean of 6 values \pm standard error.

\begin{tabular}{|c|c|c|c|c|c|c|c|c|c|}
\hline \multirow{2}{*}{$\begin{array}{l}\text { DAT } \\
60\end{array}$} & \multirow{2}{*}{$\begin{array}{l}\text { Treatments } \\
\mathrm{C} 15\end{array}$} & \multicolumn{2}{|c|}{$\begin{array}{l}\text { Roots d.m. } \\
\text { \% }\end{array}$} & \multicolumn{2}{|c|}{$\begin{array}{c}\text { Stems d.m. } \\
\%\end{array}$} & \multicolumn{2}{|c|}{$\begin{array}{c}\text { Leaves d.m. } \\
\%\end{array}$} & \multicolumn{2}{|c|}{$\begin{array}{l}\text { Fruits d.m. } \\
\qquad \%\end{array}$} \\
\hline & & 10.07 & \pm 0.2 & 32.05 & \pm 0.4 & 57.88 & \pm 0.2 & 0.00 & \pm 0.0 \\
\hline & C45 & 9.51 & \pm 0.6 & 35.86 & \pm 1.0 & 54.63 & \pm 1.2 & 0.00 & \pm 0.0 \\
\hline & MIN & 10.26 & \pm 0.5 & 29.34 & \pm 2.0 & 60.40 & \pm 2.3 & 0.00 & \pm 0.0 \\
\hline & CNT & 10.93 & \pm 0.6 & 28.05 & \pm 0.5 & 61.01 & \pm 0.2 & 0.00 & \pm 0.0 \\
\hline \multirow[t]{4}{*}{90} & $\mathrm{Cl} 5$ & 11.32 & \pm 0.8 & 43.59 & \pm 1.5 & 37.26 & \pm 1.7 & 7.83 & \pm 2.5 \\
\hline & C45 & 7.96 & \pm 0.6 & 45.67 & \pm 1.5 & 37.97 & \pm 1.4 & 8.40 & \pm 0.5 \\
\hline & MIN & 8.27 & \pm 0.9 & 44.64 & \pm 1.8 & 39.72 & \pm 2.1 & 7.37 & \pm 2.7 \\
\hline & CNT & 10.44 & \pm 0.2 & 41.88 & \pm 0.4 & 47.69 & \pm 0.6 & 0.00 & \pm 0.0 \\
\hline \multirow[t]{4}{*}{120} & $\mathrm{C} 15$ & 6.81 & \pm 0.5 & 40.26 & \pm 2.2 & 29.89 & \pm 1.4 & 23.03 & \pm 3.0 \\
\hline & C45 & 6.34 & \pm 0.4 & 44.18 & \pm 2.6 & 9.57 & \pm 2.2 & 39.91 & \pm 3.3 \\
\hline & MIN & 6.28 & \pm 0.5 & 43.38 & \pm 2.5 & 19.40 & \pm 2.1 & 30.94 & \pm 3.7 \\
\hline & CNT & 10.13 & \pm 1.2 & 42.94 & \pm 1.7 & 32.93 & \pm 1.9 & 13.99 & \pm 1.7 \\
\hline
\end{tabular}

DAT, days after transplant; d.m., dry matter.

Table 6. Bio-morphological relieves and nitrates content in the heads of endive.

\begin{tabular}{|c|c|c|c|c|c|}
\hline \multicolumn{6}{|c|}{ Endive heads } \\
\hline Treatments & Average fresh weight (g) & Head diameter (cm) & Green colour (-) & Juiciness ( $\mathrm{mg} \mathrm{H} \mathrm{H}_{2} \mathrm{O} \mathrm{cm}-2$ ) & $\mathrm{NO}^{3}-(\mathrm{ppm})$ \\
\hline $\mathrm{Cl} 5$ & $392.9^{\mathrm{d}}$ & $32.8^{\mathrm{c}}$ & Light & 91.5 & $1257^{\mathrm{b}}$ \\
\hline $\mathrm{C} 30$ & $357.1^{\mathrm{cd}}$ & $33.1^{\mathrm{c}}$ & Mean & 92.6 & $1428^{b}$ \\
\hline $\mathrm{C} 45$ & $409.5^{\mathrm{bc}}$ & $34.5^{\mathrm{bc}}$ & Mean & 94.8 & $2031^{\mathrm{ab}}$ \\
\hline MIN & $524.4^{\mathrm{a}}$ & $37.1^{\mathrm{a}}$ & Dark & 97.0 & $4205^{\mathrm{a}}$ \\
\hline $\mathrm{Cl} 15+25 \% \mathrm{~N}$ & $426.2^{b}$ & $34.6^{\mathrm{bc}}$ & Dark & 93.0 & $2452^{\mathrm{ab}}$ \\
\hline $\mathrm{C} 15+50 \% \mathrm{~N}$ & $445.8^{b}$ & $35.9^{\mathrm{ab}}$ & Dark & 93.7 & $2715^{\mathrm{ab}}$ \\
\hline CNT & $189.5^{\mathrm{e}}$ & $29.2^{\mathrm{d}}$ & Light & 87.2 & $1414^{b}$ \\
\hline I Year & 376.2 .0 & 41.2 & - & 128.3 & 1699 \\
\hline II Year & 389.40 & 26,6 & - & 73.51 & 2700 \\
\hline \multicolumn{6}{|l|}{ Effect $^{\circ}$} \\
\hline Treat. & $*$ & $*$ & - & ns & $*$ \\
\hline Year & ns & $*$ & - & * & $*$ \\
\hline Treat. $\times$ Year & ns & ns & - & ns & ns \\
\hline
\end{tabular}

a-e Numbers in the same column followed by the same letter are not significantly different for P-value $\leq 0.05$ according to Duncan's range test; ${ }^{\circ}$ Main factors of the two-way ANOVA. Asterisks indicates significance at P-value $\leq 0.05$; ns, not significant. 
Broccoli showed greater sensitivity to fertilization than endive. C15 plots showed a considerable yield increment, compared to the non-treated control, of about $170 \%$. Moreover, productivity of broccoli, on average, doubled passing from $\mathrm{C} 15$ to $\mathrm{C} 45$ or to $\mathrm{C} 15$ $+50 \% \mathrm{~N}$. The highest value of nitrates in broccoli was displayed by treatment MIN (2000 ppm), while the lowest one by $\mathrm{C} 15+25 \%$ $\mathrm{N}$ (900 ppm) (data not shown).

For the autumn-winter crops, the effect of fertilization on dry matter distribution to the different organs of plant are reported in Tables 7 and 8, for endive and broccoli, respectively. Both crops are green leafy vegetables, therefore the biomass allocated to leaves was high in all treatments already at the first sampling (Tables 7 and 8). Moreover, for these two crops, not only the control plants, but also the $\mathrm{C} 15$ plants, showed values of biomass allocated to roots statistically higher than the other two treatments.

\section{Soil analyses}

In Table 9, chemical soil characteristics, recorded at two soil depths $(0-20$ and $0-40 \mathrm{~cm})$, relative to the end of the triennial trials, are reported.

In both the soil depths $(0-20$ and $0-40 \mathrm{~cm})$ MIN treatment displayed the lowest $\mathrm{pH}$ values. EC differed only at 20-40 $\mathrm{cm}$ and treatments $\mathrm{C} 15$ and $\mathrm{C} 30$, amended with compost showed higher values than CNT. OM differed only at $0-20 \mathrm{~cm}$ and treatment $\mathrm{C} 30$ displayed the highest values, $+36 \%$ compared to CNT. CEC increased only in the first $20 \mathrm{~cm}$, and treatment C45 showed the highest values, $+14 \%$ respect to CNT. Regarding mineral elements, no significant differences for assimilable $\mathrm{P}$ were registered, whereas for exchangeable $\mathrm{K}_{2} \mathrm{O}$, treatment $\mathrm{C} 45$ displayed the highest values at both the soil depths $(0-20$ and $0-40 \mathrm{~cm})$. About the other mineral elements, exchangeable $\mathrm{Ca}$ showed the highest value under $\mathrm{C} 45$ treatment and the lowest under MIN one in the first 20 $\mathrm{cm}$; exchangeable $\mathrm{Mg}$ highlighted the highest values in $\mathrm{C} 15$ and $\mathrm{C} 30$ treatments in the first $20 \mathrm{~cm}$; exchangeable $\mathrm{Na}$ showed the highest values in $\mathrm{C} 45$ treatment at both the assessed soil depths; $\mathrm{Fe}$ and $\mathrm{Mn}$ were higher in MIN treatment than the other investigated treatments, only at 0-20 cm depth; $\mathrm{Cu}$ displayed the highest value in $\mathrm{C} 15+25 \% \mathrm{~N}$ treatment and similar value was reported in the MIN one at $20 \mathrm{~cm}$; Zn showed the highest values in C45 treatment at both the soil depths $(0-20$ and $0-40 \mathrm{~cm})$.

During the whole experimental period, nitrate content was monitored in four representative treatments $(\mathrm{C} 15, \mathrm{C} 45, \mathrm{MIN}$, and control) at two soil depths $(0-20$ and $20-40 \mathrm{~cm}$; Figures 3 and 4, respectively).

Nitrate content showed the same seasonal trend at both depths and in all treatments (Figure 3A and B); at 0-20 cm nitrate concentration was on average higher than values sampled at $20-40 \mathrm{~cm}$ depth, 22.6, 34.5, 57.2, and 19.2 vs 18.4, 25.9, 39.4, and $15.6 \mathrm{mg}$

Table 7. Effect of fertilization treatments on dry matter distribution to the different organs (average value of the two years) of endive plant in three sampling dates, expressed as days after transplant. The values are the mean of 6 values \pm standard error.

\begin{tabular}{|c|c|c|c|c|c|c|c|}
\hline $\begin{array}{l}\text { DAT } \\
30\end{array}$ & $\begin{array}{l}\text { Treatments } \\
\mathrm{C} 15\end{array}$ & \multicolumn{2}{|c|}{$\begin{array}{l}\text { Roots d.m. } \\
\%\end{array}$} & \multicolumn{2}{|c|}{$\begin{array}{c}\text { Stems d.m. } \\
\%\end{array}$} & \multicolumn{2}{|c|}{$\begin{array}{c}\text { Leaves d.m. } \\
\%\end{array}$} \\
\hline 30 & $\begin{array}{l}\text { C15 } \\
\text { C45 } \\
\text { MIN } \\
\text { CNT }\end{array}$ & $\begin{array}{l}13.1 \\
11.3 \\
11.4 \\
16.5\end{array}$ & $\begin{array}{l} \pm 0.3 \\
\pm 0.6 \\
\pm 0.6 \\
\pm 2.4\end{array}$ & $\begin{array}{l}6.9 \\
5.9 \\
4.5 \\
7.2\end{array}$ & $\begin{array}{l} \pm 1.2 \\
\pm 0.4 \\
\pm 0.6 \\
\pm 1.0\end{array}$ & $\begin{array}{l}80.0 \\
82.7 \\
84.0 \\
76.3\end{array}$ & $\begin{array}{l} \pm 0.9 \\
\pm 1.0 \\
\pm 0.1 \\
\pm 1.6\end{array}$ \\
\hline 60 & $\begin{array}{l}\text { C15 } \\
\text { C45 } \\
\text { MIN } \\
\text { CNT }\end{array}$ & $\begin{array}{c}11.3 \\
11.0 \\
8.9 \\
11.4\end{array}$ & $\begin{array}{l} \pm 0.5 \\
\pm 1.0 \\
\pm 0.3 \\
\pm 0.7\end{array}$ & $\begin{array}{l}5.6 \\
5.4 \\
6.5 \\
7.9\end{array}$ & $\begin{array}{l} \pm 1.4 \\
\pm 0.6 \\
\pm 0.7 \\
\pm 0.5\end{array}$ & $\begin{array}{l}83.1 \\
83.7 \\
84.7 \\
80.8\end{array}$ & $\begin{array}{l} \pm 1.0 \\
\pm 0.7 \\
\pm 0.6 \\
\pm 0.7\end{array}$ \\
\hline 90 & $\begin{array}{l}\text { C15 } \\
\text { C45 } \\
\text { MIN } \\
\text { CNT }\end{array}$ & $\begin{array}{c}15.5 \\
11.5 \\
9.6 \\
13.6\end{array}$ & $\begin{array}{l} \pm 0.3 \\
\pm 0.4 \\
\pm 1.6 \\
\pm 0.6\end{array}$ & $\begin{array}{l}5.1 \\
5.0 \\
5.3 \\
4.5\end{array}$ & $\begin{array}{l} \pm 0.7 \\
\pm 0.2 \\
\pm 0.4 \\
\pm 0.2\end{array}$ & $\begin{array}{l}79.4 \\
83.5 \\
85.1 \\
81.8\end{array}$ & $\begin{array}{l} \pm 0.6 \\
\pm 0.2 \\
\pm 1.8 \\
\pm 0.4\end{array}$ \\
\hline
\end{tabular}

DAT, days after transplant; d.m., dry matter.

Table 8. Effect of fertilization treatments on dry matter distribution to the different organs (average value of the two years) of broccoli plant in three sampling dates, expressed as days after transplant. The values are the mean of 6 values \pm standard error.

\begin{tabular}{|c|c|c|c|c|c|c|c|c|c|}
\hline \multirow{2}{*}{$\begin{array}{l}\text { DAT } \\
30\end{array}$} & \multirow{2}{*}{$\begin{array}{l}\text { Treatments } \\
\text { C15 }\end{array}$} & \multicolumn{2}{|c|}{$\begin{array}{c}\text { Roots d.m. } \\
\%\end{array}$} & \multicolumn{2}{|c|}{$\begin{array}{c}\text { Stems d.m. } \\
\%\end{array}$} & \multicolumn{2}{|c|}{$\begin{array}{c}\text { Leaves d.m. } \\
\%\end{array}$} & \multicolumn{2}{|c|}{$\begin{array}{c}\text { Flowers d.m. } \\
\%\end{array}$} \\
\hline & & 5.93 & \pm 0.2 & 6.75 & \pm 0.1 & 87.32 & \pm 0.4 & 0.00 & \pm 0.0 \\
\hline & C45 & 6.37 & \pm 0.2 & 7.43 & \pm 0.9 & 86.19 & \pm 0.7 & 0.00 & \pm 0.0 \\
\hline & MIN & 5.39 & \pm 0.3 & 7.90 & \pm 0.2 & 86.71 & \pm 0.3 & 0.00 & \pm 0.0 \\
\hline & CNT & 7.52 & \pm 0.1 & 9.20 & \pm 0.9 & 83.28 & \pm 1.0 & 0.00 & \pm 0.0 \\
\hline \multirow[t]{4}{*}{60} & C15 & 7.32 & \pm 0.2 & 15.82 & \pm 1.1 & 76.87 & \pm 1.0 & 0.00 & \pm 0.0 \\
\hline & C45 & 5.98 & \pm 0.1 & 15.81 & \pm 1.1 & 78.21 & \pm 1.2 & 0.00 & \pm 0.0 \\
\hline & MIN & 5.39 & \pm 0.2 & 15.93 & \pm 0.9 & 78.68 & \pm 0.7 & 0.00 & \pm 0.0 \\
\hline & CNT & 8.90 & \pm 0.7 & 11.56 & \pm 0.4 & 79.54 & \pm 0.9 & 0.00 & \pm 0.0 \\
\hline \multirow[t]{4}{*}{90} & C15 & 11.66 & \pm 0.9 & 31.78 & \pm 1.0 & 52.72 & \pm 0.4 & 3.83 & \pm 0.4 \\
\hline & $\mathrm{C} 45$ & 8.01 & \pm 0.4 & 38.94 & \pm 1.5 & 49.94 & \pm 1.4 & 3.12 & \pm 0.1 \\
\hline & MIN & 4.99 & \pm 0.2 & 32.62 & \pm 1.2 & 58.62 & \pm 1.3 & 3.77 & \pm 0.2 \\
\hline & CNT & 13.88 & \pm 0.9 & 35.19 & \pm 1.3 & 46.68 & \pm 0.7 & 4.25 & \pm 0.3 \\
\hline
\end{tabular}

DAT, days after transplant; d.m., dry matter. 
$\mathrm{kg}^{-1}$, for $\mathrm{C} 15, \mathrm{C} 45, \mathrm{MIN}$, and $\mathrm{CNT}$, respectively. In particular, MIN treatment was almost always higher than the other treatments at both depths, except in the summer 2004, when the C45 treatment reached the highest value.

Soil total nitrogen content showed different trend at 0-20 (Figure 4A) and 20-40 cm layers (Figure 4B). In the first layer, MIN and CNT treatments didn't show differences through the cycle, instead in the soil treated with MSCW, $\mathrm{N}$ had an increasing trend, with $\mathrm{C} 45$ treatment always statistically higher than the all other (Figure 4A).

At $20-40 \mathrm{~cm}$ deep, the MSCW treatments had almost constant values of soil nitrogen content during the whole experimental period, instead they significantly decreased in CNT and MIN treatments (Figure 4B).

\section{Discussion}

Findings of this research constitute an important and precious data set concerning the impact of MSWC on some of the largest and commercially popular horticultural production systems. Our results gave encouraging indications about the municipal compost ability to sustain productivity in eco-friendly and low input agricultural systems, even if different amounts of $\mathrm{N}$ were applied with MSWC treatments during the 3 investigated years. This was due to the different $\mathrm{N}$ content of the composts used in the 3 years and linked with the same amount of compost $\left(\mathrm{t} \mathrm{ha}^{-1}\right)$ applied in each treatment and in each year, following farmers and previous researcher indications. Generally, waste compost is considerate a

Table 9. Values of soil chemical elements measured at the end of the triennial crop succession used in this study.

\begin{tabular}{|c|c|c|c|c|c|c|c|}
\hline Treatments & $\mathrm{pH}$ & $\mathrm{EC}\left(\mu \mathrm{S} \mathrm{cm} \mathrm{cm}^{-1}\right)$ & OM (\%) & CEC (meq/100 g) & P (ppm) & $\mathrm{K}_{2} \mathrm{O}(\mathrm{ppm})$ & $\mathrm{Ca}(\mathrm{ppm})$ \\
\hline \multicolumn{8}{|c|}{ (0-20 cm deep) } \\
\hline $\mathrm{C} 15$ & $7.70^{\mathrm{a}}$ & $105.7^{\mathrm{ns}}$ & $1.59^{\mathrm{ab}}$ & $15.41^{\mathrm{ab}}$ & $46.3^{\text {ns }}$ & $39 g^{b c}$ & $2133^{a b}$ \\
\hline $\mathrm{C} 30$ & $7.90^{\mathrm{a}}$ & $122.3^{\text {ns }}$ & $1.84^{\mathrm{a}}$ & $15.24^{\mathrm{ab}}$ & $46.7^{\mathrm{ns}}$ & $495^{\mathrm{ab}}$ & $2033^{b c}$ \\
\hline C45 & $7.83^{\mathrm{a}}$ & $139.0^{\mathrm{ns}}$ & $1.75^{\mathrm{ab}}$ & $16.54^{\mathrm{a}}$ & $47.7^{\mathrm{ns}}$ & $562^{\mathrm{a}}$ & $2283^{a}$ \\
\hline MIN & $6.86^{\mathrm{b}}$ & $130.3^{\text {ns }}$ & $1.37^{\mathrm{ab}}$ & $15.01^{a b}$ & $51.7^{\mathrm{ns}}$ & $377^{\mathrm{c}}$ & $1850^{c}$ \\
\hline $\mathrm{Cl} 15+25 \% \mathrm{~N}$ & $7.73^{\mathrm{a}}$ & $103.0^{\mathrm{ns}}$ & $1.58^{\mathrm{ab}}$ & $15.69^{\mathrm{ab}}$ & $45.3^{\text {ns }}$ & $302^{c}$ & $2317^{\mathrm{a}}$ \\
\hline $\mathrm{Cl} 15+50 \% \mathrm{~N}$ & $7.60^{\mathrm{a}}$ & $86.9^{\text {ns }}$ & $1.52^{\mathrm{ab}}$ & $14.75^{\mathrm{ab}}$ & $43.7^{\mathrm{ns}}$ & $310^{c}$ & $2100^{a b}$ \\
\hline CNT & $7.70^{\mathrm{a}}$ & $86.7^{\mathrm{ns}}$ & $1.35^{b}$ & $14.50^{\mathrm{b}}$ & $44.0^{\mathrm{ns}}$ & $316^{c}$ & $2033^{b c}$ \\
\hline \multicolumn{8}{|c|}{ (20-40 cm deep) } \\
\hline $\mathrm{C} 15$ & $7.67^{\mathrm{ab}}$ & $103.3^{\mathrm{ab}}$ & $1.5 \mathrm{l}^{\mathrm{ns}}$ & $15.38^{\text {ns }}$ & $45.0^{\mathrm{ns}}$ & $407^{\mathrm{ab}}$ & $2117^{\mathrm{ns}}$ \\
\hline $\mathrm{C} 30$ & $7.83^{\mathrm{a}}$ & $119.3^{\mathrm{a}}$ & $1.55^{\mathrm{ns}}$ & $15.45^{\mathrm{ns}}$ & $46.3^{\text {ns }}$ & $429 \mathrm{gb}$ & $2100^{\text {ns }}$ \\
\hline C45 & $7.87^{\mathrm{a}}$ & $136.7^{\mathrm{a}}$ & $1.53^{\text {ns }}$ & $15.83^{\text {ns }}$ & $46.3^{\text {ns }}$ & $553^{\mathrm{a}}$ & $2133^{\text {ns }}$ \\
\hline MIN & $7.27^{b}$ & $110.0^{\mathrm{ab}}$ & $1.30^{\text {ns }}$ & $14.65^{\mathrm{ns}}$ & $43.0^{\text {ns }}$ & $357^{\mathrm{b}}$ & $2017^{\text {ns }}$ \\
\hline $\mathrm{C} 15+25 \% \mathrm{~N}$ & $7.70^{\mathrm{ab}}$ & $101.3^{\mathrm{ab}}$ & $1.47^{\mathrm{ns}}$ & $15.68^{\text {ns }}$ & $43.3^{\text {ns }}$ & $321^{b}$ & $2267^{\mathrm{ns}}$ \\
\hline $\mathrm{Cl} 15+50 \% \mathrm{~N}$ & $7.73^{\mathrm{ab}}$ & $95.7^{\mathrm{ab}}$ & $1.41^{\mathrm{ns}}$ & $14.75^{\mathrm{ns}}$ & $39.7^{\text {ns }}$ & $290^{b}$ & $2100^{\text {ns }}$ \\
\hline CNT & $7.77^{\mathrm{ab}}$ & $73.7^{\mathrm{b}}$ & $1.26^{\mathrm{ns}}$ & $14.73^{\mathrm{ns}}$ & $42.3^{\text {ns }}$ & $295^{b}$ & $2100^{\mathrm{ns}}$ \\
\hline Treatments & Mg (ppm) & $\mathrm{Na}(\mathrm{ppm})$ & Fe (ppm) & Mn (ppm) & $\mathrm{Cu}(\mathrm{ppm})$ & Zn (ppm) & B (ppm) \\
\hline \multicolumn{8}{|c|}{ (0-20 cm deep) } \\
\hline $\mathrm{C} 15$ & $419.3^{\mathrm{a}}$ & $53^{\mathrm{ab}}$ & $14.27^{\mathrm{b}}$ & $8.3^{b}$ & $5.4^{\mathrm{b}}$ & $2.8^{\mathrm{bc}}$ & $0.45^{\mathrm{ns}}$ \\
\hline C30 & $426.7^{\mathrm{a}}$ & $57^{\mathrm{ab}}$ & $15.20^{\mathrm{b}}$ & $8.3^{b}$ & $6.0^{\mathrm{b}}$ & $3.7^{\mathrm{ab}}$ & $0.51^{\text {ns }}$ \\
\hline $\mathrm{C} 45$ & $410.0^{\mathrm{ab}}$ & $61^{\mathrm{a}}$ & $16.27^{\mathrm{b}}$ & $8.6^{\mathrm{b}}$ & $6.0^{\mathrm{b}}$ & $4.1^{\mathrm{a}}$ & $0.53^{\text {ns }}$ \\
\hline MIN & $380.7^{\mathrm{b}}$ & $42^{b}$ & $20.47^{\mathrm{a}}$ & $24.9^{\mathrm{a}}$ & $6.4^{\mathrm{ab}}$ & $2.4^{\mathrm{bc}}$ & $0.49^{\text {ns }}$ \\
\hline $\mathrm{Cl} 15+25 \% \mathrm{~N}$ & $376.0^{\mathrm{b}}$ & $45^{\mathrm{ab}}$ & $14.20^{\mathrm{b}}$ & $10.9^{b}$ & $7.4^{\mathrm{a}}$ & $2.9^{\mathrm{bc}}$ & $0.45^{\mathrm{ns}}$ \\
\hline $\mathrm{C} 15+50 \% \mathrm{~N}$ & $393.3^{\mathrm{ab}}$ & $43^{\mathrm{ab}}$ & $13.33^{b}$ & $7.7^{\mathrm{b}}$ & $5.7^{\mathrm{b}}$ & $2.6^{\mathrm{bc}}$ & $0.50^{\text {ns }}$ \\
\hline CNT & $398.7^{\mathrm{ab}}$ & $45^{\mathrm{ab}}$ & $13.73^{b}$ & $11.0^{b}$ & $6.1^{\mathrm{b}}$ & $2.0^{c}$ & $0.47^{\mathrm{ns}}$ \\
\hline \multicolumn{8}{|c|}{ (20-40 cm deep) } \\
\hline $\mathrm{C} 15$ & $420.0^{\mathrm{ns}}$ & $59^{\mathrm{ab}}$ & $14.27^{\mathrm{ns}}$ & $8.8^{\text {ns }}$ & $5.3^{\mathrm{ns}}$ & $2.5^{\mathrm{ab}}$ & $0.43^{\mathrm{ns}}$ \\
\hline $\mathrm{C} 30$ & $420.7^{\mathrm{ns}}$ & $79^{\mathrm{a}}$ & $13.93^{\mathrm{ns}}$ & $8.5^{\mathrm{ns}}$ & $5.7^{\mathrm{ns}}$ & $2.7^{\mathrm{ab}}$ & $0.49^{\mathrm{ns}}$ \\
\hline $\mathrm{C} 45$ & $408.7^{\mathrm{ns}}$ & $80^{\mathrm{a}}$ & $16.60^{\mathrm{ns}}$ & $9.5^{\mathrm{ns}}$ & $6.0^{\mathrm{ns}}$ & $3.5^{\mathrm{a}}$ & $0.51^{\mathrm{ns}}$ \\
\hline MIN & $426.7^{\mathrm{ns}}$ & $45^{b}$ & $14.80^{\mathrm{ns}}$ & $12.7^{\mathrm{ns}}$ & $5.5^{\mathrm{ns}}$ & $2.1^{\mathrm{ab}}$ & $0.46^{\text {ns }}$ \\
\hline $\mathrm{Cl} 5+25 \% \mathrm{~N}$ & $393.3^{\text {ns }}$ & $56^{\mathrm{ab}}$ & $13.93^{\text {ns }}$ & $9.9^{\text {ns }}$ & $6.0^{\mathrm{ns}}$ & $2.5^{\mathrm{ab}}$ & $0.45^{\mathrm{ns}}$ \\
\hline $\mathrm{Cl} 15+50 \% \mathrm{~N}$ & $396.0^{\text {ns }}$ & $50^{b}$ & $13.13^{\mathrm{ns}}$ & $8.5^{\mathrm{ns}}$ & $5.5^{\mathrm{ns}}$ & $2.2^{\mathrm{ab}}$ & $0.54^{\text {ns }}$ \\
\hline CNT & $392.7^{\text {ns }}$ & $48^{b}$ & $14.33^{\text {ns }}$ & $11.1^{\mathrm{ns}}$ & $5.9^{\text {ns }}$ & $1.9^{\mathrm{b}}$ & $0.50^{\text {ns }}$ \\
\hline
\end{tabular}

EC, electrical conductivity; OM, organic matter; CEC, cation exchange capacity. Values with different letters indicate statistically significant differences for P $\leq 0.05$ according to Duncan's range test; ns, not significant. 
matter with low organic $\mathrm{N}$ content, characterized by a reduced rate of supplying nutrients by mineralization (Hébert et al., 1991; Hassen et al., 1998; Salgado et al., 2019). Therefore, it must be applied into the soil in large amounts to achieve a $\mathrm{N}$ availability equivalent to that assured by mineral fertilizers and indispensable to obtain high crop yields (Iglesias-Jimenez and Alvarez, 1993; Ali et al., 2017). For these reasons, in some conditions, it could be necessary to integrate soil compost application with synthetic $\mathrm{N}$ fertilizers to satisfy crop N requirements (Sikora and Enkiri, 2003; Han et al., 2004; Shi et al., 2004; Bouzaiane et al., 2007). In the latter circumstance, type of synthetic $\mathrm{N}$ fertilizer is also relevant for its ability to improve the nutritive value of compost (Adamtey et al., 2009; Ghaly and Alkoaik, 2010). Our crop yield responses indicated that MSWC favoured plant growth and, subsequently, reduced needs for synthetic nutritive inputs accordingly to literature (Hu and Barker, 2004; Mauromicale et al., 2011). In spring-summer crops, tomato and eggplant, production was increased by fertilization treatments compared to the control. Considering that the average tomato fruit was not influenced by the fertilization treatment, is obviously that number of fruits was positively affected by fertilization treatment. MSWC, when used at least $30 \mathrm{t} \mathrm{ha}^{-1} \mathrm{~d} . \mathrm{w}$, was able to fully replace synthetic fertilizers. Similar effect is reported by Haghighi et al. (2016) under hydroponic system, they found that adding $25 \%$ of MSWC to nutritive solilless solution increased the numbers of tomato fruits as compared with the control. In addition, it seems that MSWC, as well as the mineral fertilization, is able to accelerate the crop cycle, as demonstrated by a lower dry matter distribution to leaves, at the last sampling. MSWC positively affected tomato growth, healthy and productivity (Ghorbani et al., 2008; Giotis et al., 2008). Moreover, our field trials, have shown that the dose $\mathrm{C} 15$ was limiting for cultivation and a synthetic $\mathrm{N}$ integration (at least $25 \%$ of MIN) was necessary to reduce the gap with other treatments. Similarly, to our results, in a homologue geographic area (Apulia Region, Southern Italy) compost, synthetic $\mathrm{N}$ and their combination improved both total and marketable tomato yield, compared to a non-fertilized control (Montemurro et al., 2004). Also our results on eggplant, are in accordance with available literature. Shabani et al. (2011) reported a significant effect of the MSWC on marketable yield, number of leaves, lateral branch rate and plants height: the best rate was $50 \mathrm{t} \mathrm{ha}^{-1}$. Unfortunately, no other works assessed the feasibility of compost in the production of eggplant in open fields. This point should be addressed in future research.

Conversely to spring-summer crops, autumn-winter cultivations appeared to be more sensible to $\mathrm{N}$ supplied, probably because broccoli and endive are most $\mathrm{N}$-demanding crops (Rosen and
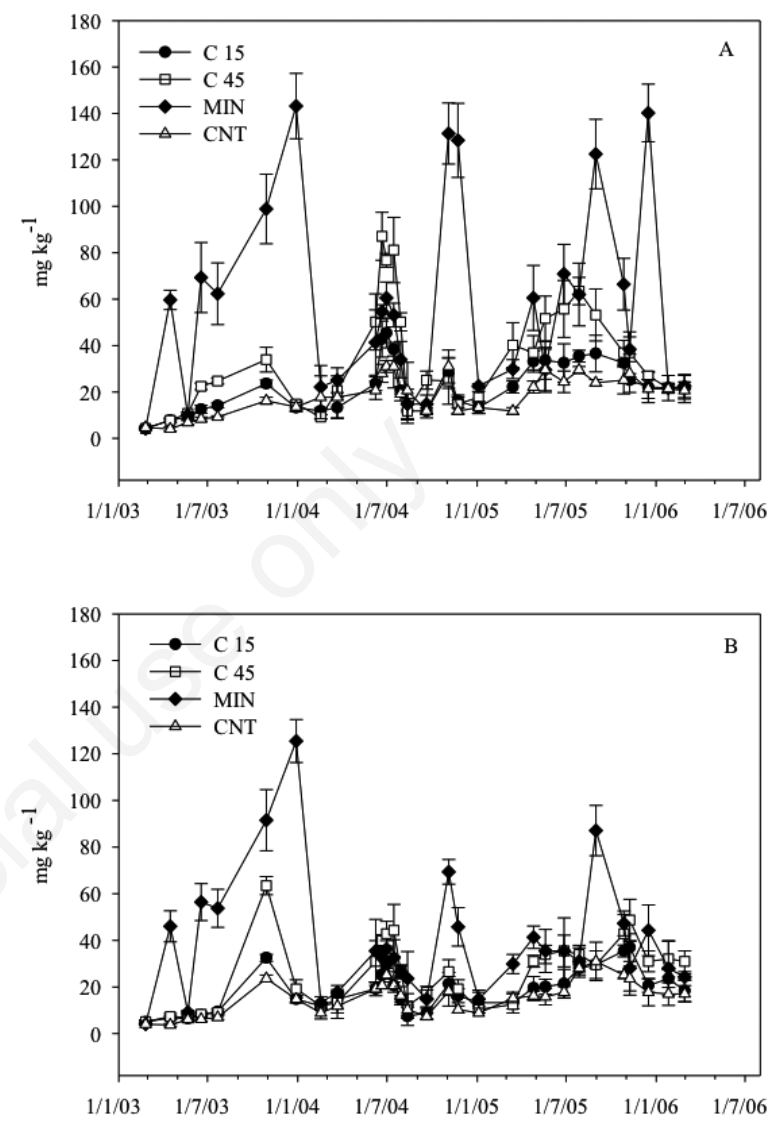

Figure 3. Soil nitrate trend over the three years test at $0-20 \mathrm{~cm}(\mathrm{~A})$ and $20-40 \mathrm{~cm}(\mathrm{~B})$ depth. Vertical bars indicate \pm standard error of means (3 replicates).
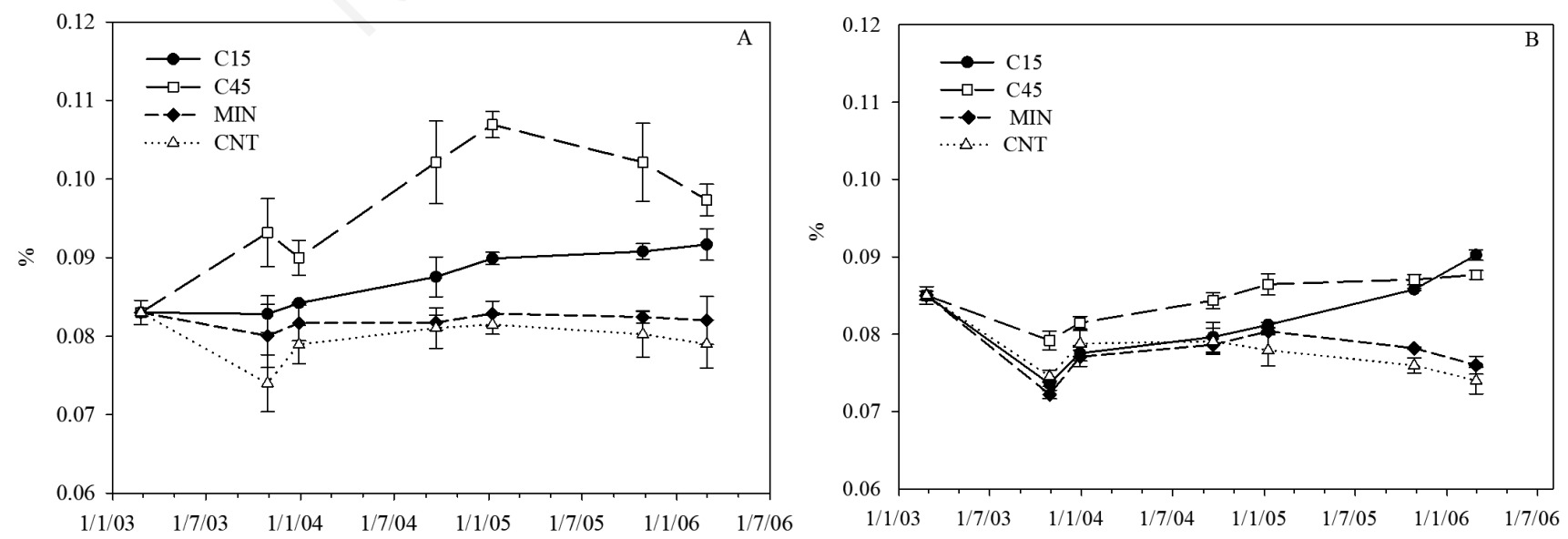

Figure 4. Total nitrogen content in the soil during the three years of test at $0-20 \mathrm{~cm}$ (A) and $20-40 \mathrm{~cm}$ (B) depth. Vertical bars indicate \pm standard error of means (3 replicates). 
Eliason, 2005). Moreover, in Mediterranean environment characterized by high rainfall in autumn-winter, the nitrogen efficiency is lower in this period, as well as the mineralization rate is lower than in spring-summer period. In fact, both in broccoli and endive, yield was significantly affected by $\mathrm{N}$ rate. Compost amendment, generally, could be able to support crop yields over time, because its positive residual soil nutrient impact (Hepperly et al., 2009; Fagnano et al., 2011). However, in our experiment, compost applied in the spring was not enable to sustain the greater yields registered for endive and broccoli with synthetic fertilizers. Actually, compost effect can be vanished by $\mathrm{N}$ losses due to leaching or its immobilization by N-requirements of soil microbiota to degrade higher inputs of organic-C (Noirot-Cosson et al., 2017).

On the other hand, according to our hypothesis of a lower nitrogen availability during this period, we also observed that both for endive and broccoli, the control plants and the plants grown on soil with the lowest dose of compost showed a slightly higher dry matter accumulation in roots than the other two treatments; it is possible that the control and $\mathrm{C} 15$ plants developed a greater root system for exploring more soil in order to find the nutrients.

MSWC application, generally, may improve soil chemical properties. At the end of the experiment, the compost contributed to the preservation of soil buffer propriety, contrarily to the acidification observed in MIN treated soils, likely due to synthetic fertilizers use, according to that reported by Srivastava et al. (2016). Furthermore, the compost limited the reduction of CEC and improved OM in the first soil layer, according to Fagnano et al. (2011) who found that after six months the treatment with the highest rate of compost $(60 \mathrm{t}$ $\mathrm{ha}^{-1}$ ) increased the organic matter. Moreover, the compost increased EC in the deepest soil layer. Nevertheless, accumulation of different ions, such as $\mathrm{Na}$ in the $20-40 \mathrm{~cm}$ soil layer was expected. This difference compared to control levels was most prevalent for $\mathrm{C} 30$ and $\mathrm{C} 45$, probably as consequence of higher leakages (Ghosh et al., 2010). Results about OM content, $\mathrm{pH}$ and $\mathrm{EC}$ in the soil, are in agreement with those also obtained in a tomato producing system (Rigane and Medhioub, 2011). Moreover, both compost treatments slightly increased the total nitrogen content, about $+13.9 \%$ on average in the top layer $0-20 \mathrm{~cm}$, so far from the more $50 \%$ increase (average value of the three compost treatments) found by Fagnano et al. (2011), but measured six months after the compost distribution. Anyway, there was not the risk of leaching this element toward the groundwater, in fact at the deeper layer $(20-40 \mathrm{~cm})$ no accumulation of nitrogen was observed. In addition, also the nitrates released by MSW compost was comparable or even lower than that of synthetic fertilizers and in line with the results of other authors in Southern Florida and in Wisconsin (Wolkowski, 2003; Jaber et al., 2005). Therefore, the compost seems to assure a good $\mathrm{N}$ availability, especially in the periods in which the mineralization rate is higher (spring-summer) and so useful to satisfy the crops nutrient needs and also improve some soil properties. Improvement of EC at 20-40 cm depth and the minimum accumulation of total $\mathrm{N}$ in the soil after three years of amendment, indicate that mineralization rate of OM was, in our experiment, rather high, with consequent accumulation of mineral elements (Weber et al., 2007) and rapid utilization of the nitrogen released, as demonstrated by growth and productivity of the crops, especially for C45. Moreover, in our study lower values of absorbable $\mathrm{Fe}, \mathrm{Mn}$, and $\mathrm{Cu}$, in the plots amended with compost were observed. However, the highest value of $\mathrm{Zn}$ in $\mathrm{C} 45$, into soil, is a value that do not cause concern in crop production. Moreover, Baldantoni et al. (2010) and Fagnano et al. (2011) reported similar results limitedly at bioavailability fractions of heavy metals, excluding a cumulative effect due to repeat waste compost application into the soil.

\section{Conclusions}

Findings of this work validated the use of MSWC as soil amendment to sustain vegetable crops in intensively open-field systems. Moreover, the present study highlights the feasibility and sustainability of agricultural land as final receptor of compost produced by municipal waste properly managed to their full recycling. Agronomical trials suggested that when compost is used at higher dose, integration with synthetic $\mathrm{N}$ may be superfluous. At a dose of $30 \mathrm{tha}^{-1}$ (d.w.), MSWC is optimal for the tested horticultural system. In fact, for spring crops, a comparable yield to that recorded only using synthetic fertilizer was displayed. In addition, MSWC application for the spring crops, offered an acceptable degree of residual fertility exploitable by successive winter crops. However, in the latter case, an integration with synthetic $\mathrm{N}$ was indispensable to reach yield levels compared to that of plots treated with synthetic fertilizers.

Moreover, MSWC also improves the soil quality, particularly with increase of organic matter, that has several beneficial effects, and of total nitrogen, also if in a less evident way. However, the MSWC shows a lower risk to leach nitrates respect the synthetic fertilization, especially in winter period.

Therefore, although the preoccupation of farmers and stakeholders about the use of MSWC is justifiable, our results have demonstrated that the right management of compost application, the choice of high-quality compost and the knowledge of crop nutrient needs and mineralization dynamics in order to reach an equilibrium, allow to obtain good results both on crops productivity and soil properties improvement.

However, findings of the present work suggested further investigations on residual effect of spring-incorporated compost to sustain winter crops.

\section{References}

Adamtey N, Cofie O, Ofosu-Budu GK, Danso SKA, Forster D, 2009. Production and storage of $\mathrm{N}$-enriched co-compost. Waste Manage. 29:2429-36.

Aggelides SM, Londra PA, 2000. Effects of compost produced from town wastes and sewage sludge on the physical properties of a loamy and a clay soil. Bioresour. Technol. 71:253-9.

Ali AF, Hassan EA, Hamad EH, Abo-Quta WMH, 2017. Effect of compost, ascorbic acid and salicylic acid treatments on growth, yield and oil production of fennel plant. Assiut. J. Agric. Sci. 48:1-1.

Albiach R, Canet R, Pomares F, Ingelmo F, 2000. Microbial biomass content and enzymatic activities after the application of organic amendments to a horticultural soil. Bioresour. Technol. 75:43-8.

Araujo AS, de Melo WJ, Singh RP, 2010 Municipal solid waste compost amendment in agricultural soil: changes in soil microbial biomass. Rev. Environ. Sci. Bio. 9:41-9.

Baldantoni D, Leone A, Iovieno P, Morra L, Zaccardelli M, Alfani A, 2010. Total and available soil trace element concentrations in two Mediterranean agricultural systems treated with municipal waste compost or conventional mineral fertilizers. Chemosphere 80:1006-13.

Bastida F, Moreno JL, Garcia C, Hernandez T, 2007a. Addition of urban waste to semiarid degraded soil: long-term effect. Pedoshphere 17:557-67. 
Bastida F, Moreno JL, Hernandez T, Garcia C, 2007b. The longterm effects of the management of a forest soil on its carbon content, microbial biomass and activity under a semi-arid climate. Appl. Soil Ecol. 37:53-62.

Bortolini S, Macavei LI, Saadoun JH, Foca G, Ulrici A, Bernini F, Malferrari D, Setti L, Ronga D, Maistrello L, 2020. Hermetia illucens (L.) larvae as chicken manure management tool for circular economy. J. Clean. Prod. 121289.

Bouzaiane O, Cherif H, Saidi N, Jedidi N, Hassen A, 2007. Effects of municipal solid waste compost application on the microbial biomass of cultivated and non-cultivated soil in a semi-arid zone. Waste Manag. Res. 25:334-42.

Bouzaiane O, Jedidi N, Hassen A, 2014. Microbial biomass improvement following municipal solid waste compost application in agricultural soil. In: D. K. Maheshwari (Ed.), Composting for sustainable agriculture. Springer, Berlin, Germany, pp 199-208.

Cala V, Cases MA, Walter I, 2005. Biomass production and heavy metal content of Rosmarinus officinalis grown on organic waste-amended soil. J. Arid Environ. 62:401-12.

Carbonell G, de Imperial RM, Torrijos M, Delgado M, Rodriguez JA, 2011. Effects of municipal solid waste compost and mineral fertilizer amendments on soil properties and heavy metals distribution in maize plants (Zea mays L.). Chemosphere 85:1614-23.

Celano G, Alluvione F, Abdel Aziz M, Spaccini R, 2012. The carbon dynamics in the experimental plots. Use of $13 \mathrm{C}$ - and $15 \mathrm{~N}-$ labelled compounds for the soil-plant balance in carbon sequestration. In: A. Piccolo (Ed.), Carbon sequestration in agricultural soils. A multidisciplinary approach to innovative methods. Springer, Düsseldorf, Germany, pp. 107-144.

Conklin AE, Erich MS, Liebman M, Lambert D, Gallandt ER, Halteman WA, 2002. Effects of red clover (Trifolium pratense) green manure and compost soil amendments on wild mustard (Brassica kaber) growth and incidence of disease. Plant. Soil. 238:245-56.

Crecchio C, Curci M, Pizzigallo MDR, Ricciuti P, Ruggiero P, 2004. Effects of municipal solid waste compost amendments on soil enzyme activities and bacterial genetic diversity. Soil Biol. Biochem. 36:1595-605.

Fagnano M, Adamo P, Zampella M, Fiorentino N, 2011. Environmental and agronomic impact of fertilization with composted organic fraction from municipal solid waste: a case study in the region of Naples, Italy. Agr. Ecosyst. Environ. 141:100-7.

Garcia-Gil JC, Ceppi SB, Velasco MI, Polo A, Senesi N, 2004. Long-term effects of amendment with municipal solid waste compost on the elemental and acidic functional group composition and $\mathrm{pH}$-buffer capacity of soil humic acids. Geoderma 121:135-42.

Garcia-Gil JC, Plaza C, Soler-Rovira P, Polo A, 2000. Long-term effects of municipal solid waste compost application on soil enzyme activities and microbial biomass. Soil Biol. Biochem. 32:1907-13.

Ghaly AE, Alkoaik FN, 2010. Effect of municipal solid waste compost on the growth and production of vegetable crops. Am. J. Agric. Biol. Sci. 5:274-81.

Ghorbani R, Koocheki A, Jahan M, Asadi GA, 2008. Impact of organic amendments and compost extracts on tomato production and storability in agroecological systems. Agron. Sustain. Dev. 28:307-11.

Ghosh S, Lockwood P, Daniel H, King K, 2010. Short-term effects of organic amendments on properties of a Vertisol. Waste
Manag. Res. 28:1087-1095.

Giotis C, Markelou E, Theodoropoulou A, Toufexi E, Hodson R, Shotton P, Shiel R. Cooper J, Leifert C, 2008. Effect of soil amendments and biological control agents (BCAs) on soilborne root diseases caused by Pyrenochaeta lycopersici and Verticillium albo-atrum in organic greenhouse tomato producing systems. Eur. J. Plant Pathol. 123:387-400.

Green SJ, Michel JFC, Hadar Y, Minz D, 2004. Similarity of bacterial communities in sawdust- and straw-amended cow manure composts. FEMS Microbiol. Lett. 233:115-23.

Guerrero C, Gomez I, Moral R, Mataix-Solera J, Mataix-Beneyto J, Hernandez T, 2001. Reclamation of a burned forest soil with municipal waste compost: macronutrient dynamic and improved vegetation cover recovery. Bioresour. Technol. 76:221-7.

Haghighi M, Barzegar MR, da Silva, JAT, 2016. The effect of municipal solid waste compost, peat, perlite and vermicompost on tomato (Lycopersicum esculentum L.) growth and yield in a hydroponic system. Int. J. Recycl. Org. Waste Agric. 5:23142.

Han KH, Choi WJ, Han GH, Yun SI, Yoo SH, Ro HM, 2004. Ureanitrogen transformation and compost-nitrogen mineralization in three different soils as affected by the interaction between both nitrogen inputs. Biol. Fertil. Soils 39:193-9.

Hargreaves JC, Adl MS, Warman PR, 2008a. A review of the use of composted municipal solid waste in agriculture. Agr. Ecosyst. Environ. 123:1-14.

Hargreaves JC, Adl MS, Warman PR, Rupasinghe HPV, 2008b. The effects of organic and conventional nutrient amendments on strawberry cultivation: fruit yield and quality. J. Sci. Food Agric. 88:2669-75.

Hargreaves JC, Adl MS, Warman PR, Rupasinghe HPV, 2008c. The effects of organic amendments on mineral element uptake and fruit quality of raspberries. Plant. Soil. 308:213-26.

Hassen A, Jedidi N, Cherif M, M'Hiri A, Boudabous A, van Cleemput O, 1998. Mineralization of nitrogen in a clayey loamy soil amended with organic wastes enriched with $\mathrm{Zn}, \mathrm{Cu}$ and Cd. Bioresour. Technol. 64:39-45.

Hébert M, Karam A, Parent LE, 1991. Mineralization of nitrogen and carbon in soils amended with composted manure. Biol. Agric. Hortic. 7:349-61.

Hepperly P, Lotter D, Ziegler UC, Seidel R, Reider C, 2009. Compost, manure and synthetic fertilizer influences crop yields, soil properties, nitrate leaching and crop nutrient content. Compost Sci. Util. 17:117-26.

$\mathrm{Hu}$ Y, Barker AV, 2004. Evaluation of composts and their combinations with other materials on tomato growth. Comm. Soil Sci. Plant Anal. 35:2789-807.

Iglesias-Jimenez E, Alvarez CE, 1993. Apparent availability of nitrose in composted municipal refuse. Biol. Fertil. Soils 16:313-8

Iovieno P, Morra L, Leone A, Pagano L, Alfani A, 2009. Effect of organic and mineral fertilizers on soil respiration and enzyme activities of two Mediterranean horticultural soils. Biol. Fertil. Soils 45:555-61.

Jaber FH, Shukla S, Stoffella PJ, Obreza T, Hanlon EA, 2005. Impact of organic amendments on groundwater nitrogen concentrations for sandy and calcareous soils. Compost. Sci. Util. 13:194-202.

Kjeldahl C, 1883. A new method for the determination of nitrogen in organic matter. Z. Anal. Chem. 22:366.

Kowaljow E, Mazzarino MJ, Satti P, Rodriguez CJ, 2010. Organic and inorganic fertilizer effects on a degraded Patagonian 
rangeland. Plant. Soil. 332:135-45.

Kowaljowa E, Mazzarino M, 2007. Soil restoration in semiarid Patagonia: chemical and biological response to different compost quality. Soil. Biol. Biochem. 39:1580-8.

Lakhdar A, Rabhi M, Ghnaya T, Montemurro F, Jedidi N, Abdelly C, 2009. Effectiveness of compost use in salt-affected soil. J. Hazard Mater. 171:29-37.

Mathivanan S, Chidambaram AL, Sundaramoorthy PA, Kalaikandhan R, 2012. Effect of vermicompost on germination and biochemical constituents of groundnut (Arachis hypogaea L.) seedling. Int. J. Res. Biol. Sci. 2:54-9.

Mauromicale G, Longo AMG, Lo Monaco A, 2011. The effect of organic supplementation of solarized soil on the quality of tomato fruit. Sci. Hortic. 129:189-96.

Montemurro F, Maiorana M, Convertini GE, Ferri D, 2004. Risposte produttive, qualitative e nutrizionali del pomodoro da industria alla fertilizzazione organica con RSU-compost. Agroindustria 3:29-33.

Noirot-Cosson PE, Dhaouadi K, Etievant V, Vaudour E, Houot S, 2017. Parameterisation of the NCSOIL model to simulate $C$ and $\mathrm{N}$ short-term mineralisation of exogenous organic matter in different soils. Soil. Biol. Biochem. 104:128-40.

Pagano L, Iovieno P, Zaccardelli M, Morra L, 2008. Soil organic matter dynamic as affected by municipal food waste compost fertilization in Southern Italy. Adv. GeoEcol. 34:357-70.

Pane C, Villecco D, Zaccardelli M, 2010. Response of microbial communities to compost amendment of soil and effect on disease suppressiveness. J. Plant. Pathol. S4:92-93.

Pane C, Spaccini R, Piccolo A, Scala F, Bonanomi G, 2011. Compost amendments enhance peat suppressiveness to Pythium ultimum, Rhizoctonia solani and Sclerotinia minor. Biol. Control 56:115-24.

Pane C, Celano G, Villecco D, Zaccardelli M, 2012c. Control of Botrytis cinerea, Alternaria alternata and Pyrenochaeta lycopersici on tomato with whey compost-tea applications. Crop Prot. 38:80-86.

Pane C, Villecco D, Campanile F, Zaccardelli M, 2012b. Novel strains of Bacillus, isolated from compost and compostamended soils, as biological control agents against soil-borne phytopathogenic fungi. Biocontrol Sci. Technol. 22:1373-88.

Pane C, Villecco D, Zaccardelli M, 2012a. Short-time response of microbial communities to waste compost amendment of an intensive cultivated soil in Southern Italy. Comm. Soil Sci. Plant Anal. 44:2344-52.

Paradelo R, Moldes AB, González D, Barral MT, 2012. Plant tests for determining the suitability of grape marc composts as components of plant growth media. Waste Manag. Res. 30:105965.

Pedra F, Polo A, Ribeiro A, Domingues H, 2007. Effects of municipal solid waste compost and sewage sludge on mineralization of soil organic matter. Soil Biol. Biochem. 39:1375-82.

Pinamonti F, Stringari G, Zorzi G, 1997. Use of compost in soilless cultivation. Compost Sci. Util. 5:38-46.

Ramos MC, Martınez-Casasnovas JA, 2006. Erosion rates and nutrient losses affected by composted cattle manure application in vineyard soils of NE Spain. Catena 68:177-85.

Rigane MK, Medhioub K, 2011. Assessment of properties of Tunisian agricultural waste compost: application as components in reconstituted anthropic soils and their effects on tomato yield and quality. Resour. Conser. Recy. 55:785-92.

Ronga D, Francia E, Allesina G, Pedrazzi S, Zaccardelli M, Pane C, Tava A, Bignami C, 2019a. Valorization of vineyard byproducts to obtain composted digestate and biochar suitable for nursery grapevine (Vitis vinifera L.) production. Agronomy 9:420.

Ronga D, Mantovi P, Pacchioli MT, Pulvirenti A, Bigi F, Allesina G, Pedrazzi S, Tava A, Dal Prà A, 2020a. Combined effects of dewatering, composting and pelleting to valorize and delocalize livestock manure, improving agricultural sustainability. Agronomy 10:661.

Ronga D, Pane C, Zaccardelli M, Pecchioni N, 2016. Use of spent coffee ground compost in peat-based growing media for the production of basil and tomato potting plants. Comm. Soil Sci. Plant Anal. 47:356-68.

Ronga D, Parisi M, Pentangelo A, Mori M, Di Mola I, 2019c. Effects of nitrogen management on biomass production and dry matter distribution of processing tomato cropped in southern Italy. Agronomy 9:855.

Ronga D, Pentangelo A, Parisi M, 2020b. Optimizing N fertilization to improve yield, technological and nutritional quality of tomato grown in high fertility soil conditions. Plants 9:575.

Ronga D, Villecco D, Zaccardelli, M, 2019b. Effects of compost and defatted oilseed meals as sustainable organic fertilisers on cardoon (Cynara cardunculus L.) production in the Mediterranean basin. J. Hortic. Sci. 94:664-75.

Rosen CJ, Eliason R, 2005. Nutrient management for commercial fruit \& vegetable crops in Minnesota. University of Minnesota Extension Service, St. Paul, MN, USA.

Sah RN, 1994. Nitrate-nitrogen determination - a critical review. Comm. Soil Sci. Plant Anal. 25:2841-69.

Salgado M, Blu RO, Janssens M, Fincheira P, 2019. Grape pomace compost as a source of organic matter: Evolution of quality parameters to evaluate maturity and stability. J. Clean. Prod. 216:56-63.

Sarkar D, Ferguson M, Datta R, Birnbaum S, 2005. Bioremediation of petroleum hydrocarbons in contaminated soils: comparison of biosolids addition, carbon supplementation, and monitored natural attenuation. Environ. Pollut. 136:187-95.

Semple KT, Reid BJ, Fermor TR, 2001. Impact of composting strategies on the treatment of soils contaminated with organic pollutants. Environ. Pollut. 112:269-83.

Setti L, Francia E, Pulvirenti A, Gigliano S, Zaccardelli M, Pane C, Caradonia F, Bortolini S, Maistrello L, Ronga, D, 2019. Use of black soldier fly (Hermetia illucens (L.), Diptera: Stratiomyidae) larvae processing residue in peat-based growing media. Waste Manage. 95:278-88.

Shabani H, Peyvast GA, Olfati JA, Kharrazi PR, 2011. Effect of municipal solid waste compost on yield and quality of eggplant. Comun. Sci. 2:85-90.

Shi W, Miller BE, Stark JM, Norton JM, 2004. Microbial nitrogen transformations in response to treated dairy waste in agricultural soils. Soil Sci. Soc. Am. J. 68:1867-74.

Shiralipour A, McConnell DB, Smith WH, 1992. Uses and benefits of MSW compost: a review and an assessment. Biomass Bioenerg. 3:267-79.

Sikora LJ, Enkiri NK, 2003. Availability of poultry litter compost $\mathrm{P}$ to fescue compared with tripple super phosphate. Soil Sci. 168:192-9.

Singh RP, Agrawal M, 2008. Potential benefits and risks of land application of sewage sludge. Waste Manag. 28:347-58.

Singh RP, Agrawal M, 2010. Variations in heavy metal accumulation, growth and yield of rice plants grown at different sewage sludge amendment rates. Ecotox. Environ. Safe. 73:632-41.

Srivastava V, De Araujo ASF, Vaish B, Bartelt-Hunt S, Singh P, Singh RP, 2016. Biological response of using municipal solid 
waste compost in agriculture as fertilizer supplement. Rev. Environ. Sci. Bio. 15:677-96.

SSSA (Soil Science Society of America), 1996. Methods of soil analysis, Part 3 - Chemical methods. Soil Science Society of America, Madison, WI, USA.

Tejada M, Garcia C, Gonzalez JL, Hernandez MT, 2006. Use of organic amendment as a strategy for saline soil remediation: influence on the physical, chemical and biological properties of soil. Soil Biol. Biochem. 38:1413-21.

Warman PR, Burnham JC, Eaton LJ, 2009. Effects of repeated applications of municipal solid waste compost and fertilizers to three lowbush blueberry fields. Sci. Hortic. 122:393-8.

Weber J, Karczewska A, Drozd J, Licznar M, Licznar S, Jamroz E, Kocowicz A, 2007. Agricultural and ecological aspects of a sandy soil as affected by the application of municipal solid waste composts. Soil Biol. Biochem. 39:1294-302.

Weber J, Kocowicz A, Bekier J, Jamroz E, Tyszka R, Debicka M, Parylak D, Kordas L, 2014. The effect of a sandy soil amend- ment with municipal solid waste (MSW) compost on nitrogen uptake efficiency by plants. Eur. J. Agron. 54:54-60.

Wolkowski RP, 2003. Nitrogen management considerations for landspreading municipal solid waste compost. J. Envir. Quality 32:1844-50.

Zaccardelli M, Pane C. Scotti R, Palese AM, Celano G, 2012. Impiego di compost-tea come bioagrofarmaci e biostimolanti in orto-frutticoltura. Italus Hortus 19:17-28.

Zaccardelli M, Perrone D, Del Galdo A, Giordano I, Villari G, Bianco M, 2006. Multidisciplinary approach to validate compost use in vegetable crop systems in Campania Region (Italy): effect of compost fertilization on processing tomato in field cultivation. Acta Hortic. 700:285-8.

Zucconi F, De Bertoldi M, 1986. Organic waste stabilization throughout composting and its compatibility with agricultural uses. In: D.L. Wise (Ed.), Global bioconversion. CRC Press, Boca Raton, FL, USA, pp. 109-137. 